\title{
PRC1 Sustains the Memory of Neuronal Fate Independent of PRC2 Function
}

Ayana Sawai ${ }^{1}$, Sarah Pfennig ${ }^{1}$, Milica Bulajić ${ }^{2}$, Alexander Miller ${ }^{1}$, Alireza Khodadadi-

Jamayran $^{3}$, Esteban O. Mazzoni ${ }^{2}$, Jeremy S. Dasen ${ }^{1 *}$

${ }^{1}$ Neuroscience Institute, Department of Neuroscience and Physiology, NYU School of Medicine,

New York, NY 10016, USA

${ }^{2}$ Department of Biology, New York University, New York, NY 10003, USA

${ }^{3}$ Applied Bioinformatics Laboratories, Office of Science and Research, NYU School of

Medicine, New York, NY 10016, USA

*Corresponding author: jeremy.dasen@nyumc.org 


\section{Abstract}

2

Polycomb repressive complexes (PRCs) 1 and 2 maintain stable cellular memories of

4 early fate decisions by establishing heritable patterns of gene repression. PRCs repress

5 transcription through histone modifications and chromatin compaction, but their roles in

6 neuronal subtype diversification are poorly defined. We unexpectedly found that PRC2 is

7 dispensable to preserve the morphogen-induced positional fates of spinal motor neurons (MNs),

8 while PRC1 is essential for the specification of segmentally-restricted subtypes. Mutation of the

9 core PRC1 component Ringl in mice leads to increased chromatin accessibility and ectopic

10 expression of a broad variety of fates determinants, including Hox transcription factors, while

11 neuronal class-specific features are maintained. Loss of MN subtype identities in Ring 1 mutants

12 is due to the suppression of Hox networks by derepressed caudal Hox genes. These results

13 indicate that PRC1 can function independently of de novo PRC2-dependent histone methylation

14 to maintain chromatin topology and transcriptional memory at the time of neuronal

15 differentiation. 


\section{Introduction}

Accurate control of gene expression is essential for the specification and maintenance of neural fates during development. Studies of cell type-restricted transcription factors have illuminated the mechanisms by which spatial and temporal regulation of gene expression gives rise to identifiable neuronal subtypes (Doe, 2017; Fishell and Kepecs, 2020; Hobert and Kratsios, 2019; Sagner and Briscoe, 2019; Venkatasubramanian and Mann, 2019). A parallel and critical mechanism of gene regulation is through the post-translational modification of histones, which enables and restricts transcription by modifying chromatin structure (Kishi and Gotoh, 2018; Schuettengruber et al., 2017). The Polycomb group (PcG) is key family of histone-associated proteins that play evolutionarily conserved roles in restricting gene expression during development (Blackledge et al., 2015; Gentile and Kmita, 2020; Simon and Kingston, 2009; Soshnikova and Duboule, 2009). In embryonic stem cells, cell fate determinants are repressed through PRC activities, and PRC-associated histone marks are subsequently removed from loci as cells differentiate (Boyer et al., 2006; Farcas et al., 2012; Tavares et al., 2012). PRC repression is maintained through cell division and after differentiation, and is thought to contribute to stable cellular memories of early patterning events (Ciabrelli et al., 2017; Coleman and Struhl, 2017). In vertebrates, much of our knowledge of how PRCs regulate gene expression has emerged from biochemical studies of PcG proteins or from the activity of these factors in proliferating cells. Despite an in depth understanding of the mechanisms of PRC action, how PcG proteins interact with gene regulatory networks in the CNS remains poorly understood.

The specification of neuronal fates in the vertebrate spinal cord provides a tractable system to elucidate the function of PcG proteins, as the pathways that determine identities are well-defined, and the molecular signatures of many subtypes are known (Butler and Bronner, 2015; Sagner and Briscoe, 2019). One neuronal class where fate specification has been closely examined is the spinal MN. A core set of transcription factors, including Hb9, Isl1/2, and Lhx3, determines class-specific features of MNs, including neurotransmitter identity (Shirasaki and Pfaff, 2002). The subsequent diversification of MNs into hundreds of muscle-specific subtypes is achieved through a conserved network of Hox transcription factors differentially expressed along the rostrocaudal axis (Philippidou and Dasen, 2013). During neural tube patterning, opposing gradients of retinoic acid (RA) and fibroblast growth factors (FGFs) provide spinal progenitors 
with a positional identity (Bel-Vialar et al., 2002; Dasen et al., 2003; Liu et al., 2001). These morphogens act, in part, by temporally and spatially depleting Polycomb-associated histone marks from Hox clusters (Mazzoni et al., 2013; Narendra et al., 2015). As progenitors exit the cell cycle, MNs continue to express Hox genes, where they regulate repertoires of subtypespecific genes (Catela et al., 2016; Dasen et al., 2005; Mendelsohn et al., 2017). Although the role of Hox proteins in the CNS are well-characterized (Parker and Krumlauf, 2020), and are known targets of PRC activities (Gentile and Kmita, 2020), the specific contributions of PRC1 and PRC2 to CNS maturation remain unclear, as few studies have directly compared their functions during embryonic development.

Polycomb repression is initiated by PRC2, which methylates histone $\mathrm{H} 3$ at lysine-27, permitting recruitment of PRC1 through subunits that recognize this mark, leading to chromatin compaction at genes targeted for repression (Margueron and Reinberg, 2011; Schuettengruber et al., 2017). PRC1 and PRC2 can also exist in a variety of configurations, which may contribute to neuronal subtype-specific activities. The core subunit of PRC1, Ring1, binds to one of six Polycomb group Ring finger (Pcgf) proteins (Gao et al., 2012). PRC1 containing Pcgf4 interacts with Cbx proteins (canonical PRC1) which recognize H3K27me3 (Bernstein et al., 2006; Morey et al., 2012). Variant forms of PRC1 containing Rybp can inhibit incorporation of Cbx proteins into PRC1, and bind target loci independent of H3K27me3 (Tavares et al., 2012; Wang et al., 2010). We previously found that a PRC1 component, Pcgf4, is required to establish rostral boundaries of Hox expression in differentiating MNs (Golden and Dasen, 2012). By contrast, deletion of a core PRC2 component, Ezh2, from MN progenitors had no apparent impact on fate specification, possibly due to compensation by Ezhl (Shen et al., 2008), or through use of variant PRC1 containing Rybp. These observations raise the question of what are the specific roles of canonical PRC1, variant PRC1, and PRC2 during MN subtype diversification.

To determine the function of PRCs during neural differentiation, we removed core components of these complexes from MN progenitors. We found that depletion of Ring1 proteins, essential constituents of all PRC1 isoforms, causes pronounced changes in transcription factor expression and a loss of Hox-dependent MN subtypes. Surprisingly, neither PRC2 nor variant PRC1 activities are required for rostrocaudal patterning at the time of MN differentiation. Deletion of Ring 1 leads to increased chromatin accessibility and derepression of a broad variety 
of cell fate determinants, while class-specific features of MNs are preserved. The derepression of caudal Hox genes in Ringl mutants leads to the suppression of MN subtype diversification programs. These findings indicate that PRC1 can preserve the memory of early patterning events in the CNS.

\section{Results}

\section{PRC1 is Essential for Rostrocaudal Patterning During Neuronal Differentiation}

To determine the relative contributions of PRC1 and PRC2 to neuronal specification, we analyzed mice in which core subunit-encoding genes were selectively removed from $\mathrm{MN}$ progenitors. Ezh genes encode the methyltransferase activity of PRC2, while Eed is required to enhance this function. We first generated mice in which both $E z h$ genes are conditionally deleted, by breeding Ezh1 and Ezh2 floxed lines to Olig2::Cre mice, which targets Cre to MN progenitors ( $E z h^{M N \Delta}$ mice) (Hidalgo et al., 2012; Su et al., 2003). We confirmed MN-restricted loss of PRC2 activity by examining the pattern of $\mathrm{H} 3 \mathrm{~K} 27 \mathrm{me} 3$ at E11.5, which was selectively depleted from progenitors and post-mitotic MNs (Figure 1A,B). Expression of Hb9 and Vacht, two general markers of MN identity, were grossly unchanged in $E z h^{M N \Delta}$ mice. (Figure $\left.1 \mathrm{C}, \mathrm{D}, \mathrm{G}\right)$. We next analyzed expression of Hox proteins in $E z h^{M N \Delta}$ mice and found that the MN columnar subtype determinants Hoxc6, Hoxc9, and Hoxc10, were all expressed in their normal domains (Figure 1E,F, Supplementary Figure 1A-C). Similarly, we observed no changes in Hb9, Hoxc6, Hoxc9, and Hoxc10 expression in MNs after removal of the PRC2 component Eed, using Sox 1::Cre (Eed ${ }^{N E \Delta}$ mice), which targets Cre to neuroectoderm (Supplementary Figure 1D-H) (Takashima et al., 2007; Yaghmaeian Salmani et al., 2018). Depletion of PRC2 activity from neural progenitors therefore does not affect MN class specification or rostrocaudal patterning.

We next investigated the function of PRC1, which is thought to repress gene expression in a PRC2-dependent manner. We generated mice in which RinglB is conditionally deleted from MN progenitors using Olig2::Cre in a global RinglA mutant background (Ring $1^{M N \Delta}$ mice) (Cales et al., 2008; del Mar Lorente et al., 2000). In Ring $1^{M N \Delta}$ mice, Ring1B protein was selectively removed from progenitors and post-mitotic MNs (Figure 1H,I). The number of $\mathrm{Hb}^{+} \mathrm{MNs}$ and pattern of Vacht expression were similar to controls in Ring $1^{M N \Delta}$ mice (Figure 1J,K,N). By contrast, Hox proteins normally expressed by forelimb-innervating brachial MNs were not 
113

114

115

116

117

118

119

120

121

122

123

124

125

126

127

128

129

130

131

132

133

134

135

136

137

138

139

140

141

142

143

144

detected, while thoracic and lumbar Hox proteins were ectopically expressed in more rostral MNs (Figure 1L,M,O-T, Supplementary Figure 1I,J,K). Brachial-level Hox proteins (Hoxc4, Hoxa5, Hoxc6 and Hoxc8), were selectively depleted from MNs, while thoracic and lumbar Hox determinants, (Hoxc9, Hoxc10, and Hoxd10) were derepressed in brachial segments (Figure 1QT). At thoracic levels Hoxc9 expression was attenuated and Hoxd10 was ectopically expressed (Supplementary Figure 1J). These results show that loss of Ringl leads to a marked rostral shift in Hox pattern, without affecting pan-MN molecular features (Figure 1O).

\section{Canonical PRC1 Regulates Hox Expression in MNs}

Ring1 can interact with multiple Pcgf proteins, raising the question of which PRC1 configuration contributes to MN patterning. PRC1 containing Pcgf4 is required to establish Hox boundaries in MNs (Golden and Dasen, 2012), but can exist in two alternative configurations, depending on mutually exclusive incorporation of Cbx (canonical PRC1) or Rybp (variant PRC1) (Gao et al., 2012; Tavares et al., 2012). We examined the function of PRC1 isoforms first by manipulating Rybp and Cbx expression in MNs. We hypothesized that if canonical PRC1 regulates Hox expression, then overexpression of Rybp would inhibit binding of Cbx to Ring1, leading to MN phenotypes similar to Ring1 mutants (Figure 1U). We used chick in ovo neural tube electroporation to express Rybp in postmitotic MNs using the $H b 9$ promoter $(H b 9:: m R y b p)$. Expression of $m R y b p$ under $H b 9$ led to ectopic Hoxc9 and Hoxc10 expression at brachial levels (Figure 1V). If Rybp acts by displacing Cbx, then elevating Cbx levels should restore normal Hox expression. To test this, we co-electroporated $H b 9:: m R y b p$ and $H b 9:: m C b x 2$ at equivalent plasmid concentration, and no longer observed ectopic Hoxc9 in brachial segments (Figure 1X).

These observations are consistent with canonical PRC1 containing Pcgf4, Cbx, and Ring1 restricting Hox expression in MNs. Rybp is expressed by MNs at the time of their differentiation (Supplementary Figure 1L), raising the possibility that Rybp (or its paralog Yaf2) also plays regulatory roles during development. We therefore selectively deleted Rybp from MNs using Olig2::Cre mice in a Yaf2-/- background (Rybp/Yaf $2^{M N \Delta}$ mice). Combined deletion of Rybp and Yaf2 did not affect MN generation, Hoxc6, Hoxc9, or Hoxc10 expression (Supplementary Figure 1L). These findings indicate that canonical PRC1 maintains appropriate Hox expression, while variant PRC1 and PRC2 do not contribute to rostrocaudal patterning at the time of MN differentiation. 


\section{PRC1 is Required for MN Subtype Diversification}

Hox transcription factors play central roles in establishing neuronal subtype identities through regulating expression of subtype-specific genes. To determine the consequences of altered Hox expression in Ring $1^{M N \Delta}$ mice, we analyzed the molecular profiles and peripheral innervation pattern of MNs. A key Hox target in MNs is the transcription factor Foxp1, which is essential for the differentiation of limb-innervating lateral motor column (LMC) and thoracic preganglionic column (PGC) neurons (Dasen et al., 2008; Rousso et al., 2008). In Ring $1^{M N \Delta}$ mice, Foxp1 expression is lost from brachial and thoracic MNs, and markedly reduced in lumbar MNs (Figure 2A,B,G, Supplementary Figure 2C). By contrast, in $E z h^{M N A}, E e d^{N E A}$ and $R y b p / Y a f 2^{M N \Delta}$ mice, Foxp1 expression was maintained, consistent with the preservation of normal Hox profiles in these mutants (Supplementary Figure 1L, 2A,B). In Ring $1^{M N A}$ mice, expression of the LMC marker Raldh2 was lost at brachial levels, and the thoracic PGC marker nNos was not detected (Figure 2C, D). Moreover, expression of determinants of respiratory phrenic MNs $\left(\operatorname{Scip}^{+}\right.$Isl1/2 ${ }^{+}$), was markedly depleted, and likely contributes to the perinatal lethality of Ring $1^{M N \Delta}$ mice (Supplementary Figure 2D). These results indicate that Ringl deletion leads to a loss of genes acting downstream of Hox function in MNs.

We next assessed the impact of Ringl deletion on two MN subtypes that are specified independent of Hox function, the hypaxial and median motor columns (HMC and MMC). In Ring $1^{M N \Delta}$ mice, MMC neurons $\left(\mathrm{Lhx}^{+} \mathrm{Hb}^{+}\right)$were generated at normal numbers in thoracic segments, while the number of HMC neurons (Is11/2 ${ }^{+} \mathrm{Hb}^{+} \mathrm{Lhx} 3^{-}$) was increased in thoracic and brachial segments (Figure 2E,F,H, Supplementary Figure 2E,F). The increase in HMC neurons in Ring 1 mutants is likely due to a reversion of presumptive Hox-dependent subtypes to an HMC fate, similar to mice in which Hox function is disrupted (Dasen et al., 2008; Hanley et al., 2016). Mutation in Ringl therefore depletes Hox-dependent subtypes, with the remaining MNs having a more ancestral axial identity (Figure 2P).

As we observed a dramatic loss of segmentally-restricted MN subtypes in $\operatorname{Ring} 1^{M N \Delta}$ mice,

174 we next assessed the impact on peripheral innervation pattern. To trace motor axon projections, 175 we crossed Ring $1^{M N A}$ mice to an $H b 9:: G F P$ reporter, in which all MN axons are labelled with 176 GFP. In control mice there are nine primary trajectories of forelimb-innervating motor axon at 
177

178

179

180

181

182

183

184

185

186

187

188

189

190

191

192

193

194

195

196

197

198

199

200

201

202

203

204

205

206

207

208

E12.5 (Figure 2I,J) (Catela et al., 2016). In Ring $1^{M N A}$ mice, only three nerve branches, radial, median, and ulnar were visible but appeared prematurely truncated and unbranched (Figure $2 \mathrm{~K}$ ). In the trunk, innervation of sympathetic chain ganglia was lost, consistent with a loss of PGC fates (Figure 2L,M). Projections to dorsal and ventral axial muscles by MMC and HMC subtypes were maintained in Ring $1^{M N \Delta}$ mice, although axons were shorter than in controls (Figure 2N, O). Loss of Ringl therefore causes severe defects in innervation pattern, while the trajectories of axial MNs are relatively spared.

\section{Loss of Ring1 Causes Broad Derepression of Developmental Fate Determinants}

Polycomb proteins regulate diverse aspects of differentiation by restricting gene expression during development. To investigate changes in gene expression after deletion of Ringl genes in an unbiased manner, we performed RNAseq on MNs isolated from Ring ${ }^{M N \Delta}$ mice. We purified MNs from control and Ring $1^{M N A} ; H b 9:: G F P$ embryos at E12.5 by flow cytometry ( $\mathrm{n}=4$ Ring 1 mutants, and $\mathrm{n}=4 \mathrm{Cre}^{-}$controls), and performed RNAseq. Because Ring 1 mutants display segment-specific phenotypes, we collected MNs from brachial, thoracic, and lumbar levels and profiled each population independently.

We identified a total of 1001 upregulated and 641 downregulated genes in Ring $1^{M N \Delta}$ mice $\left(\log _{2}-\mathrm{FC}>2, \mathrm{FDR}<0.1\right)$, with 391 genes upregulated in all three segmental regions, compared to 46 genes that were commonly downregulated (Figure 3A-C, Supplementary Figure 3A,C, Table 1). Thus, many upregulated genes are shared between each segment, while downregulated genes tended to be segment-specific. Strikingly, $76 \%$ of the top 100 derepressed genes (by $\log _{2}-\mathrm{FC}$ ) at brachial levels encode transcription factors, and include genes normally involved in the specification of spinal interneurons (e.g. Gata3, Shox2, Lhx2), brain regions (FoxG1, Six6, Lhx8), and non-neuronal lineages (Figure 3B).

Although a variety of cell fate determinants were derepressed in $\operatorname{Ring} 1^{M N \Delta}$ mice, our RNAseq analyses provide further evidence that core molecular determinants of MN class identity are preserved in Ringl mutants. We found no significant changes in transcription factors (Isll, Isl2, Hb9, Lhx3, Lhx4), guidance molecules (Slit2, Robo1, Robo2, DCC) and neurotransmitter genes (Chat, Acly) associated with pan-MN features (Figure 3D). There was a modest decrease in expression Slc18a3 (Vacht) (Figure 3D). Expression of genes that mark other excitatory 
(Slc17a7, Slc17a6) or inhibitory (Slc32a1, Gad2, Gad1,) neuronal classes were not markedly changed in Ring1 mutants (Supplementary Figure 3B). By contrast, expression of genes associated with MN subtype identities was decreased in Ring $I^{M N \Delta}$ mice, including genes that mark limb-innervating (e.g Foxp1, Etv4, Raldh2, Runx1), thoracic-specific (Nos1, Cyp26b), and respiratory (Alcam, Ptn) subtypes (Figure 3E).

To validate these changes in gene expression, we performed mRNA in situ hybridization on a subset of upregulated or downregulated genes. We found that Gata3, Lhx8, and $\operatorname{Lhx} 2$ were markedly upregulated in MNs of Ring $1^{M N A}$ mice (Figure 4A-F), while other genes (Foxg1, Six6, Pitx2, Shox2, Nkx2.1) showed less prominent, but detectable, ectopic expression (Supplementary Figure 4A-J). We also examined expression of previously uncharacterized genes that were downregulated in all three segmental regions. We found Rgs 4 , Uts $2 b$, Vat1, and Gabra2 were expressed by MNs of control embryos, and were downregulated in Ring 1 mutants (Figure 4G-L, Supplementary Figure 4K,L). These results indicate that despite the derepression of multiple fate determinants in Ring $I^{M N \Delta}$ mice, core features of MN identity are preserved, but that subtype diversification programs are selectively disrupted.

\section{Selective Derepression of Caudal Hox genes in Ring ${ }^{M N A}$ mice}

As our preliminary analyses revealed altered expression in a subset of Hox genes in Ring $1^{M N A}$ mice, we further evaluated Hox genes in our RNAseq dataset. Consistent with the analysis of Hox protein expression, rostral Hox genes were reduced in brachial segments of Ring $1^{M N A}$ mice, while Hox 10-Hoxl3 genes were derepressed (Figure 5A, Supplementary Figure 5A-C). We observed derepression of caudal Hox genes from each of the four vertebrate Hox clusters, including genes not normally detectable in the ventral spinal cord (e.g HoxB genes) (Dasen et al., 2005) (Figure 5A, Supplementary Figure 5A-C). The extent of caudal Hox derepression correlated with the relative position of genes within a cluster, with Hoxl3 genes displaying the most pronounced derepression in Ring $1^{M N A}$ mice (by FC), relative to other caudal Hox genes (Figure 5B, Supplementary Figure 3C). The marked derepression of Hoxl3 genes was observed in each of the three segmental levels we analyzed, while Hox 10 genes were selectively derepressed in brachial and thoracic segments (Figure 5A, Supplementary Figure 5A-C). 
To further validate these findings, we analyzed Hox13 expression by in situ hybridization. In controls Hoxc13 is restricted to sacral segments, while Hoxb13 is not detected in MNs (Figure 5C). In Ring $1^{M N A}$ mice, both Hoxb13 and Hoxc13, were de-repressed in MNs throughout the rostrocaudal axis (Figure 5C). By contrast, in situ hybridization of Hoxc6 and Hoxc 9 expression revealed reduced expression at brachial and thoracic levels, respectively (Supplementary Figure 5C). Thus, ectopic expression of Hoxl3 genes in Ringl mutants is associated with a loss of rostral Hox gene expression.

\section{Ring1 is Essential to Maintain MN Chromatin Topology}

Our findings indicate that in the absence of Ringl genes, a broad variety of cell fate determinants are ectopically expressed in MNs, while only a subset of caudal Hox genes are derepressed. As PRC1 restricts gene expression through chromatin compaction, we investigated whether removal of Ringl leads to changes in DNA accessibility at derepressed loci. We used Assay for Transposase-Accessible Chromatin with high-throughput sequencing (ATACseq) to identify genomic regions which have gained or lost accessibility in Ring $1^{M N A}$ mice. We purified $H b 9:: G F P^{+}$MNs at E12.5 from control and Ring $1^{M N A}$ embryos at brachial, thoracic, and lumbar levels, and performed ATACseq. In control samples, we observed a progressive opening of caudal Hox genes in more rostral segments. For example, the accessibility of Hox9 genes increases from brachial to thoracic segments, while HoxlO and Hoxl1 genes are more accessible in lumbar segments (Supplementary Figure 6A, B). ATACseq profiles between MNs of control and Ring $1^{M N \Delta}$ mice. We identified a total of 2,305 loci that gained accessibility in Ring $1^{M N \Delta}$ embryos, 324 (14\%) of which were common to all three segmental levels (Figure 6A, Table 2). Common genes included caudal Hox genes (Hoxa13, Hoxc13) and other transcription factors (e.g. Foxg1, Lhx2, Pitx2) that were derepressed in our RNAseq analyses (Figure 6C). We also identified 1,264 loci that lost accessibility in Ring $1^{M N \Delta}$ mice, 39 (3\%) of which were common to all three segments (Figure 6A). Thus, similar to our RNAseq results, loss of Ringl leads to increased accessibility in many genes that are shared among each segment, while genes that lose accessibility tend to be segment-specific. 
To assess which genes may be directly repressed by PRC1, we examined the overlap

272 between transcripts that were upregulated and loci that gained accessibility in Ring $1^{M N \Delta}$ mice.

273 We found that $18 \%$ (148/813) of genes that were ectopically expressed at brachial segments also

274 gained accessibility in Ring $1^{M N \Delta}$ mice (Figure 6B). We found 19 genes, including Hoxal3 and

275 Hoxc13, were derepressed and gained accessibly in all three segments (Supplementary Figure

276 6C). Since lumbar segments still retain features of Hox-dependent subtypes, we also compared

277 the overlap between genes that were upregulated and gained accessibility in brachial and thoracic

278 MNs. We identified 73 genes, $56(77 \%)$ of which encode transcription factors, including each of

279 the caudal Hox genes we found by RNAseq (Figure 6B, Supplementary Figure 6C). The gain of

280 accessibility at transcription factor-encoding genes was prominent near transcription start sites

281 (Figure 6C), and regions that gained accessibility in Ring $1^{M N \Delta}$ neurons correspond to regions shown to be bound by Ring1B in ES cells (Supplementary Figure 6D) (Bonev et al., 2017).

In agreement with our RNAseq analysis, Hox 13 paralogs showed pronounced increases in accessibility, with each of the four Hoxl3 genes gaining accessibility in each of the three segmental levels (Figure 6D,E). By contrast, rostral Hox4-Hox8 genes, which are transcriptionally downregulated in Ringl mutants, were not among that targets that lost accessibility (Figure 6D). These results suggest that reduced expression of rostral Hox4-Hox9 genes in Ring 1 mutants is not due to a loss in chromatin accessibility.

\section{Hox13 Paralogs Represses Rostral Hox genes by Engaging Accessible Chromatin Domains}

As PRC1-mediated chromatin compaction is essential for Hox repression, it is surprising that Hox4-Hox9 genes are diminished in Ringl mutants, without a noticeable reduction in chromatin accessibility at these loci (Supplementary Figure 6D). Because cross-repressive interactions between Hox genes themselves are an important regulatory mechanism determining Hox boundaries (Philippidou and Dasen, 2013), it is possible that ectopically expressed Hox 13 genes directly repress multiple Hox genes in Ring $1^{M N \Delta}$ mice. To test this, we first analyzed MNs derived from ES cells (ESC-MNs) in which Hoxc13 expression can be induced upon doxycycline (Dox) treatment (Bulajic et al., 2020). ESC-MNs differentiated via RA and Sonic Hedgehog agonist are characterized by expression of Hox4-Hox5 paralogs. RNAseq analyses revealed that Hoxa4, Hoxa5, Hoxc4, and Hoxc5 expression were markedly reduced after Doxinduced Hoxc13 expression in MN progenitors, compared to non-induced ESC-MNs (Figure 7A, 
Supplementary Figure 7A-C). This repressive effect also appears to be direct, as ChIPseq analysis indicates that Hoxc13 can bind at multiple Hox genes (Figure 7A).

Hox 13 proteins can target inaccessible chromatin (Bulajic et al., 2020; Desanlis et al., 2020), while repression by the Drosophila Hox protein Ubx is associated with chromatin compaction (Loker et al., 2021). To examine the possible effects of Hox 13 proteins on local chromatin structure, we compared accessibility at Hox loci in both control and Ringl mutants, relative to the location of Hoxc13 binding sites. At Hox4-Hox5 genes, Hoxc13 sites correspond to regions that are accessible in both control and Ring1 mutant MNs (Figure 7A, Supplementary Figure 7A-C). Hox13 proteins therefore appear to repress rostral Hox genes, in part, through binding at pre-existing accessible regions.

To test whether Hoxl3 genes can repress multiple Hox paralogs in vivo, we used chick neural tube electroporation to express Hoxl3 genes within brachial, thoracic, and lumbar segments, and assessed Hox4-Hox10 gene expression. We electroporated pCAGGs::mHoxa13ires-nucGFP or pCAGGs::mHoxb13-ires-nucGFP and found that both cell-autonomously repressed expression of brachial, thoracic, and lumbar Hox proteins (Hoxc4, Hoxa5, Hoxc6, Hoxc8, Hoxc9, and Hoxc10) (Figure 7B-D). By contrast, misexpression of Hox13 genes did not affect expression of the general MN markers Is11/2 and Hb9 (Figure 7B-D). These results indicate that Hox 13 proteins can directly repress multiple Hox genes, and likely contribute to the MN fate specification defects of Ring $1^{M N \Delta}$ mice.

\section{Discussion}

The Polycomb group encompass a large and diverse family of proteins essential for maintaining epigenetic memory of early patterning events. Classically, PcG-mediated repression is thought to depend on recruitment of PRC1 through recognition of histone methylation marks deposited by PRC2 activity. Although alternative, H3K27me3-independent, mechanisms of PRC1 repression have been described (Gao et al., 2012; Tavares et al., 2012), the relative contribution of PRC1 and PRC2 to neuronal fate specification have not been resolved. In this study, we found that genetic depletion of PRC2 components has no discernable impact on neural class or subtype differentiation programs at the time of MN differentiation. By contrast, a core 
PRC1 subunit, Ring1, is required to restrict transcription factor expression in the CNS, maintain neuronal subtype-specific chromatin topology, and determine rostrocaudal boundaries of Hox expression. Our findings indicate PRC1 plays an key role in regulating expression of cell fate determinants during $\mathrm{MN}$ differentiation, safeguarding neurons from acquiring inappropriate gene regulatory programs.

\section{PRC Functions in Neural Development}

Polycomb proteins function in diverse aspects of CNS maturation, including the temporal transition from neurogenesis to gliogenesis, maintenance of adult neural stem cell fates, and restriction of gene expression in mature neurons (Di Meglio et al., 2013; Fasano et al., 2009; Hirabayashi et al., 2009; Molofsky et al., 2003; von Schimmelmann et al., 2016). The role of PRCs in neural subtype diversification has been challenging to study, in part, due the complexity and dynamic temporal regulation of its constituents. By selectively removing core PRC1 and PRC2 subunits from neural progenitors, we determined the relative contributions of these chromatin-associated complexes to neuronal diversification. We found that PRC1 represses a broad variety of cell fate determinants, with the majority of highly derepressed genes in Ring 1 mutants encoding transcription factors. Ectopic expression of Ring1-regulated targets is associated with a disruption in chromatin topology, resulting in a gain in accessibility of derepressed genes.

Despite the derepression of multiple fate determinants in the absence of PRC1 function, expression of transcription factors that define MN class identity (e.g. Hb9, Isl1/2, and Lhx3), are largely unchanged, and MNs do not acquire characteristics of other neuronal classes. This observation suggests that once a class identity has been established, ectopic expression of fate determinants is insufficient to respecify basic neuronal features, such as neurotransmitter identity. In C. elegans the ability of transcription factors to reprogram neuronal class identity requires removal of histone deacetylase proteins (Tursun et al., 2011), suggesting that additional regulatory constraints, such as histone acetylation and/or DNA-methylation, restricts the ability of ectopic transcription factors to interfere with class-specific programs in Ringl mutants.

While basic elements of MN fate are maintained in the absence of PRC1, their differentiation into molecularly distinct subtypes is severely compromised. The loss of subtype- 
specific programs in brachial and thoracic segments can be attributed to the attenuation of Hox4Hox9 paralog expression, as mice lacking these Hox genes show a similar loss in MN subtype features (Jung et al., 2010; Jung et al., 2014; Philippidou et al., 2012). Selective loss of Hox function in MNs also appears to account for the observation that the majority of downregulated genes in Ringl mutants are segment-specific.

We found that removal of PRC1 leads to the derepression and increased accessibility of caudal Hox genes. Loss of PRC1 does not result in a sustained derepression of all Hox genes, as of Ring1. These findings are reminiscent of the function of PRCs in Drosophila, where loss of PRC function leads to ectopic expression of the caudal Hox gene Abd-b and repression of $U b x$ expression (Struhl and Akam, 1985; Struhl and White, 1985), likely reflecting cross-repressive interactions between caudal Hox proteins and rostral Hox genes. Notably, reduced rostral Hox gene expression in Ring 1 mutants is not a reflection of reduced chromatin accessibility at these targets, consistent with a model in which this form of repression is not associated with global changes in chromatin structure.

In Ringl mutants, Hoxl3 genes are derepressed in MNs, and appear to contribute to the loss of MN subtypes. Derepression of Hoxl3 genes alone does not appear to account for all of the specification defects in Ringl mutants, as Hox10 genes were expressed normally in lumbar segments. Hoxc9 can also repress Hox4-Hox8 genes in MNs through direct binding (Jung et al., 2010), and likely contributes to the Ringl mutant phenotype. Derepression of multiple caudal Hox paralogs therefore appears to have a cumulative effect on repressing brachial and thoracic Hox genes. In conjunction with studies in Drosophila, these finding indicate a deeply-conserved mechanism of rostrocaudal patterning, in which PRCs establish and maintain rostral Hox boundaries, while Hox cross-repressive interactions define caudal boundaries.

\section{PRC2-Independent Functions of PRC1 in Maintaining Neuronal Subtype Fate}

Studies of neuronal and non-neuronal development provide compelling evidence that PRC2 activity is required to restrict gene expression in early development (Ezhkova et al., 2009; Gentile et al., 2019; Snitow et al., 2015; Yaghmaeian Salmani et al., 2018). An unexpected 
finding from our studies is that MN subtype differentiation and Hox boundaries are maintained after removal of PRC2 activity. Mutation of Ezh genes or Eed depletes H3K27me3 from progenitors and postmitotic neurons, without appreciably affecting MN generation, Hox expression, or downstream Hox effectors. These observations indicate that neural progenitors can acquire independence from continuous PRC2 activity to restrict gene expression, whereas there is an absolute requirement for PRC1 function to maintain appropriate transcription factor expression and chromatin organization.

How does PRC1 restrict expression of fate determinants in the absence of PRC2 activity? One possibility is that residual $\mathrm{H} 3 \mathrm{~K} 27 \mathrm{me} 3$, below the threshold of histological detection, is transmitted through cell division and is sufficient to recruit canonical PRC1 and maintain target gene repression. As cells divide, newly synthesized histones are presumably devoid of H3K27me3 in PRC2 mutants, leading to replication-coupled dilution of H3K27me3. During neural differentiation, the rate of cell division decreases (Kicheva et al., 2014; Wilcock et al., 2007), potentially limiting $\mathrm{H} 3 \mathrm{~K} 27 \mathrm{me} 3$ reduction, and enabling PRC1 to bind at target loci, even

414 in the absence of de novo H3K27 methylation. Although we observed no MN phenotypes in Ezh 415 or Eed mutants, later-born oligodendrocytes that derive from the same precursors as MNs have 416 been shown to depend on PRC2 function for their differentiation (Wang et al., 2020). This more 417 pronounced effect on glial development likely reflects further dilution of H3K27me3 through 418 cell division in PRC2 mutants. independently of de novo H3K27 methylation. Repression by canonical PRC1 has been shown to 422 depend on the formation of phase-separated subnuclear structures (Polycomb bodies) assembled 423 through polymerization of Polyhomeotic-like (Phc) and/or Cbx proteins (Isono et al., 2013; Plys 424 et al., 2019; Tsuboi et al., 2018). Mutation of Phc2 in mice leads to ectopic expression of Hox 425 genes, with Hox13 genes among the most robustly derepressed targets (Isono et al., 2013). One 426 possibility is that PcG-mediated repression may not depend on anchoring of PRC1 through H3K27me3, but is maintained through Phc-mediated chromatin compaction at specific loci. 
expression in MNs. These activities are likely deployed prior to neural progenitor specification, as recent studies have demonstrated that the establishment of rostrocaudal positional identities can be specified before neural induction (Metzis et al., 2018). Patterning morphogens, such as RA and FGF, may initially act on stem cells to establish the pattern of H3K27me3 at Hox loci prior to neurogenesis. This early rostrocaudal patterning step may ultimately serve to coordinate Hox expression in the neural tube and surrounding mesodermally-derived tissues. The subsequent switch to reliance on PRC1 function could reflect a general mechanism of gene regulation in neuronal subtypes that become terminally differentiated during development.

\section{Materials and Methods}

\section{Mouse Genetics}

Ezh1 flox (Hidalgo et al., 2012), Ezh2 flox (Su et al., 2003), Olig2::Cre (Dessaud et al., 2007), Hb9::GFP (Arber et al., 1999) mice have been previously described. Ring1A-/-; Ring 1B flox (Cales et al., 2008; del Mar Lorente et al., 2000) and Rybp flox; Yaf2-/- (Hisada et al., 2012; Rose et al., 2016) mouse lines were generated by microinjection of the mouse ESCs expressing these constructs into the blastocyst followed by implantation of these eggs into pseudopregnant foster female mice. Generation of Ezh $h^{M N \Delta}$ mice was performed by crossing Ezh1 flox, Ezh2 flox and Olig2::Cre. Ezh $h^{M N \Delta}$ mice are viable at birth but do not survive beyond P20. Generation of Ring $1^{M N \Delta}$ mice was performed by crossing Ring $1 A-/-;$ Ring $1 B$ flox and Olig2::Cre. Ring $1^{\text {MNA }}$ mice perish at birth. Generation of Ring $1^{M N \Delta} ; H b 9:: G F P$ mice was performed by crossing Ring1A-/-; Ring1B flox, Olig2::Cre mice to Hb9::GFP mice. Animal work was approved by the Institutional Animal Care and use Committee of the NYU School of Medicine in accordance to NIH guidelines.

\section{Slide Immunohistochemistry}

Embryos were fixed in 4\% PFA for 1.5-2 hours at $4^{\circ} \mathrm{C}$, washed 5-6 times in cold PBS for 15-30 minutes each wash, and incubated overnight in $30 \%$ sucrose. Tissue was embedded in OCT, frozen in dry ice, and sectioned at $16 \mu \mathrm{m}$ on a cryostat. For antibody staining of sections, slides of cryosections were placed in PBS for 5 minutes to remove OCT. Sections were then transferred to humidified trays and blocked for 20-30 minutes in $0.75 \mathrm{ml} / \mathrm{slide}$ of PBT (PBS, $0.1 \%$ Triton) 
containing $1 \%$ Bovine serum albumin (BSA). The blocking solution was replaced with primary staining solution containing antibodies diluted in PBT with $0.1 \%$ BSA. Primary antibody staining was performed overnight at $4{ }^{\circ} \mathrm{C}$. Slides were then washed three times for 5 minutes each in PBT. Fluorophore-conjugated secondary antibodies were diluted 1:500-1:1000 in PBT and filtered through a $0.2 \mu \mathrm{m}$ syringe filter. Secondary antibody solution was added to slides $(0.75$ $\mathrm{ml} / \mathrm{slide}$ ) and incubated at room temperature for 1 hour. Slides were washed three times in PBT, followed by a final wash in PBS. Coverslips were placed on slides using $110 \mu \mathrm{l}$ of Vectashield (Vector Laboratories).

Antibodies against Hox proteins and MN subtypes were generated as described (Dasen et al., 2008; Dasen et al., 2005). Additional antibodies were used as follows: goat anti-Ring1B (Abcam, 1:2000), rabbit anti-Ring1B (Abcam, 1:5000), rabbit anti-Rybp (Abcam1:2000), rabbit anti-Yaf2 (Abcam, 1:2000), rabbit anti-Cbx2 (Bethyl, 1:5000), rabbit anti-H3K27me3 (Cell Signaling, 1:2000).

\section{In situ mRNA Hybridization}

Probe templates were generated by RT-PCR and incorporated a T7 promoter sequence in the antisense strand. Total RNA was first extracted from eviscerated E12.5 embryos using TRIzol (Invitrogen). Genes of interest were amplified with the One Taq One-Step RT-PCR kit (NEB) using $1 \mu \mathrm{g}$ of RNA. After amplification by RT-PCR, a second PCR was performed to incorporate a T7 promoter sequence. Antisense riboprobes were generated using the Digoxigenin-dUTP (SP6/T7) labeling kit (Sigma-Aldrich). For in situ hybridization, sections were first dried for 10-15 minutes at room temperature, placed in 4\% PFA, and fixed for 10 minutes at room temperature. Slides were then washed three times for 3 minutes each in PBS, and then placed in Proteinase $\mathrm{K}$ solution $(1 \mu \mathrm{g} / \mathrm{ml})$ for 5 minutes at room temperature. After an additional PFA fixation and washing step, slides were treated in triethanolamine for 10 minutes, to block positive charges in tissue. Slides were then washed three times in PBS and blocked for 2-3 hours in hybridization solution (50\% formamide, 5X SSC, 5X Denhardt's solution, 0.2 $\mathrm{mg} / \mathrm{ml}$ yeast RNA, $0.1 \mathrm{mg} / \mathrm{ml}$ salmon sperm DNA). Prehybridization solution was removed, and replaced with $100 \mu \mathrm{l}$ of hybridization solution containing $100 \mathrm{ng}$ of DIG-labeled antisense probe. Slides were then incubated overnight $\left(12-16\right.$ hours) at $72^{\circ} \mathrm{C}$. After hybridization, slides were 
transferred to a container with $400 \mathrm{ml}$ of $5 \mathrm{X} \mathrm{SSC}$ and incubated at $72^{\circ} \mathrm{C}$ for 20 minutes. During this step, coverslips were removed using forceps. Slides were then washed in $400 \mathrm{ml}$ of $0.2 \mathrm{X}$ SSC for 1 hour at $72^{\circ} \mathrm{C}$. Slides were transferred to buffer B1 $(0.1 \mathrm{M}$ Tris $\mathrm{pH} 7.5,150 \mathrm{mM} \mathrm{NaCl})$ and incubated for 5 minutes at room temperature. Slides were then transferred to staining trays and blocked in $0.75 \mathrm{ml} /$ slide of $\mathrm{B} 1$ containing $10 \%$ heat inactivated goat serum. The blocking solution was removed and replaced with antibody solution containing $1 \%$ heat inactivated goat serum and a 1:5000 dilution of anti-DIG-AP antibody (Roche). Slides were then incubated overnight at $4^{\circ} \mathrm{C}$ in a humidified chamber. The following day, slides were washed 3 times, 5 minutes each, with $0.75 \mathrm{ml} / \mathrm{slide}$ of buffer B1. Slides were then transferred to buffer B3 (0.1 M Tris $\mathrm{pH} 9.5,100 \mathrm{mM} \mathrm{NaCl}, 50 \mathrm{mM} \mathrm{MgCl} 2$ ) and incubated for 5 minutes. Slides were then developed in $0.75 \mathrm{ml} / \mathrm{slide}$ of B3 solution containing $3.5 \mu \mathrm{l} / \mathrm{ml}$ BCIP and $3.5 \mu \mathrm{l} / \mathrm{ml}$ NBT for 12 48 hours. After color development, slides were washed in $\mathrm{ddH}_{2} \mathrm{O}$ and coverslipped in Glycergel (Agilent). A more detailed in situ hybridization protocol is available on our lab website (http://www.dasenlab.com).

\section{Wholemount Immunohistochemistry}

For wholemount immunohistochemistry embryos were fixed in PFA for 2 hours, then bleached for 24 hours at $4{ }^{\circ} \mathrm{C}$ in a $10 \% \mathrm{H}_{2} \mathrm{O}_{2}, 10 \%$ DMSO solution prepared in methanol. Embryos were washed three times for 10 minutes each in methanol, followed by five washes for 10 minutes in PBS. Primary antibodies were diluted in staining solution (5\% BSA, 20\% DMSO in PBS) and specimens were incubated in staining solution on a rotator overnight at room temperature. Samples were then washed three times for 5 minutes each in PBS, followed by four 1 hour washes in PBS. Specimens were then incubated in secondary antibodies diluted in staining solution overnight at room temperature. Samples were then washed three times for 5 minutes each in PBS, followed by four 1 hour washes in PBS, a single 10 min wash in 50\% methanol, and three 20 minute washes in 100\% methanol. Samples were transferred to glass depression slides and tissue was cleared by incubating samples in BABB solution (1-part benzyl alcohol: 2parts benzyl benzoate). Confocal images of embryos were obtained from Z-stacks using Zen software (Zeiss). Further details of wholemount staining protocols are available on our lab website: (http://www.dasenlab.com). 


\section{In ovo chick electroporation}

In ovo electroporation were performed on Hamburger Hamilton $(\mathrm{HH})$ stage 13-14 chick embryos and analyzed at HH stage 24-25. Fertilized chicken eggs (Charles River) were incubated in a humidified incubator at $39^{\circ} \mathrm{C}$ for $40-48$ hours until they reached $\mathrm{HH} 13-14$. The top of the egg shell was removed and a $1 \mu \mathrm{g} / \mu \mathrm{LNA}(150-500 \mathrm{ng} / \mu \mathrm{L}$ expression plasmid and $\mathrm{pBKS}$ carrier DNA) containing $\sim 0.02 \%$ Fast green was injected into the central canal of the neural tube using a sharpened glass capillary tube. Electrodes (Platinum/Iridium $(80 \% / 20 \%), 250 \mu \mathrm{m}$ diameter, UEPMGBVNXNND, FHC Inc.) were placed on both sides of the neural tube (4 mm separation) and DNA was electroporated using an ECM 830 electroporator (ECM 830, BTX; 25V, 4 pulses, $50 \mathrm{~ms}$ duration, 1 second interval). Eggs were sealed with parafilm and incubated for 48 hours prior to fixation. Results shown in figures are representative of at least 3 electroporated embryos from two or more experiments in which electroporation efficiency in MNs was above $60 \%$.

\section{RNA preparation and Library Preparation}

RNA was extracted from FACS purified MNs dissected from E12.5 mouse embryo (10-20,000 cells/segment), using the Arcturus Picopure RNA isolation kit. For on-column DNase treatment, Turbo DNase was used (ambion, AM2238). Each samples used separated bar code for libraries. RNA quality and quantity were measured with an Agilent Picochip using a Bioanalyzer, all samples had quality scores between 9-10 RIN. For library preparation 10ng of total RNA was used to generate cDNA, which was amplified with SMARTer Stranded RNA-Seq kit. 100ng of cDNA were used as input to prepare the libraries (Takara, \#634837), and amplified by 10 PCR cycles. Samples were run in four 50-nucleotide paired-end read rapid run flow cell lanes with the Illumina HiSeq 4000 sequencer.

\section{RNAseq Data Analyses}

Sequencing reads were mapped to the assembled reference genome (mm10) using the STAR aligner (v2.5.0c) (Dobin et al., 2013). Alignments were guided by a Gene Transfer Format (GTF) file. The mean read insert sizes and their standard deviations were calculated using Picard tools (v.1.126) (http://broadinstitute.github.io/picard). The read count tables were generated using HTSeq (v0.6.0) (Anders et al., 2015), normalized based on their library size factors using DEseq2(Love et al., 2014), and differential expression analysis was performed. The Read Per Million (RPM) normalized BigWig files were generated using BEDTools (v2.17.0) (Quinlan and 
Hall, 2010) and bedGraphToBigWig tool (v4). To compare the level of similarity among the samples and their replicates, we used two methods: principal-component analysis and Euclidean distance-based sample clustering. All the downstream statistical analyses and generating plots were performed in R environment (v3.1.1) (https://www.r-project.org/ ).

\section{ATACseq}

ATACseq was performed following previously described protocols(Buenrostro et al., 2015). DNA was extracted from purified dissected mouse embryonic MNs. Cells were aliquoted and washed twice in ice-cold $1 \times$ PBS. Cell pellets were resuspended in $10 \mathrm{mM}$ Tris (pH 7.4), $10 \mathrm{mM}$ $\mathrm{NaCl}, 3 \mathrm{mM} \mathrm{MgCl}$, 0.1\% NP-40 (v/v), 0.1\% tween20, 0.01\% Digitonin and 1\% BSA, centrifuged at $500 \mathrm{~g}$ for $5 \mathrm{~min}$ at $4^{\circ} \mathrm{C}$. Pellets were resuspended in $12.5 \mu 1$ of $2 \times$ tagmentation DNA buffer, $1.25 \mu 1$ Tn5 (Nextera DNA Sample Preparation Kit, FC-121-1030) and $11.25 \mu 1$ of water, and incubated at $37^{\circ} \mathrm{C}$ for $30 \mathrm{~min}$. The sample was purified using the MinElute PCR Purification Kit (Qiagen, 28004). PCR enrichment of the library was performed with customdesigned primers and 2× NEB Master Mix. A qPCR reaction with $1 \times$ SYBR Green (Invitrogen), custom-designed primers and 2× NEB Master Mix (New England Labs, M0541) was performed to determine the optimal number of PCR cycles (one third of the maximum measured fluorescence)(Buenrostro et al., 2013). The libraries were purified using the AMPure XP beads (Beckman Coulter, A63880). High Sensitivity DNA ScreenTape (Agilent, 5067-5584) was used to verify the fragment length distribution of the library. Library quantification was performed using the KAPA Library Amplification kit on a Roche LightCycler 480. The libraries were sequenced on an Illumina NovaSeq (100 cycles, paired-end).

\section{ATACseq data analysis}

All of the reads from the Sequencing experiment were mapped to the reference genome (mm10) using the Bowtie2 (v2.2.4)(Langmead and Salzberg, 2012) and duplicate reads were removed using Picard tools (v.1.126) (http://broadinstitute.github.io/picard/). Low quality mapped reads $(\mathrm{MQ}<20)$ were removed from the analysis. The read per million (RPM) normalized BigWig files were generated using BEDTools (v.2.17.0) (Quinlan and Hall, 2010) and the bedGraphToBigWig tool (v.4). Peak calling was performed using MACS (v1.4.2)(Zhang et al., 2008) and peak count tables were created using BEDTools. Differential peak analysis was 
588

589

590

591

592

593

594

595

596

597

598

599

600

601

602

603

604

605

606

607

608

609

610

611

612

613

614

615

616

617

618

performed using DESeq2 (Love et al., 2014). ChIPseeker (v1.8.0)(Yu et al., 2015) R package was used for peak annotations and motif discovery was performed using HOMER (v4.10)(Heinz et al., 2010). ngs.plot (v2.47) and ChIPseeker were used for TSS site visualizations and quality controls. KEGG pathway analysis and Gene Ontology (GO) analysis was performed using the clusterProfiler R package (v3.0.0)(Yu et al., 2012). To compare the level of similarity among the samples and their replicates, we used two methods: principal-component analysis and Euclidean distance-based sample clustering. The downstream statistical analyses and generating plots were performed in R environment (v3.1.1) (https://www.r-project.org/).

\section{Statistics}

Samples sizes were determined based on previous experience and the number of animals and definitions of $\mathrm{N}$ are indicated in the main text and figure legends. In figures where a single representative image is shown, results are representative of at least two independent experiments, unless otherwise noted. No power analysis was employed, but sample sizes are comparable to those typically used in the field. Data collection and analysis were not blind. Graphs of quantitative data are plotted as means with standard error of mean (SEM) as error bars, using Prism 8 (Graphpad) software. Unless noted otherwise, significance was determined using unpaired t-test in Prism 8 software, or using adjusted p-values. Exact p-values are indicated, where appropriate, in the main text, figures, and figure legends.

\section{Data Availability}

RNAseq and ATACseq data are available through GEO (GSE175503).

\section{Acknowledgements}

We thank Kristen D'Elia, Sara Fenstermacher, Jessica Treisman, and Ed Ziff for discussion and comments on the manuscript, and Rachel Kim and Orly Wapinski for assistance. We thank Isabel Hidalgo and Susana Gonzalez for providing Ezhlflox mice, Alexander Tarakhovsky for Ezh2 flox mice, Stefan Thor for Eed mutant embryos, Haruhiko Koseki for Ring1A-/-;Ring1B flox ES cells, and Robert Klose for Rybp flox; Yaf2-/- ES cells. We also thank Genome Technology Center and Cytometry and Cell Sorting Laboratory at NYU Langone. This work was supported by NIH NINDS grants T32 GM007238, F31 NS087772 to AS, R01NS100897 to EOM, R35 NS116858, R01 NS062822 and R01 NS097550 to JD. 


\section{Author Contributions}

621 A.S. and J.S.D. designed experiments, interpreted data, and wrote the paper. S.P. performed in

622 situ hybridizations. A.M. and A.S. performed chick neural tube experiments. M.B. and E.O.M

623 designed and performed mouse ESC experiments. A.S. performed all mouse genetic analyses

624 and performed RNAseq and ATACseq. A. K.-J. analyzed ATACseq and RNAseq data.

625

\section{Declaration of Interests}

627 The authors declare no competing interests.

628 


\section{References}

Anders, S., Pyl, P.T., and Huber, W. (2015). HTSeq--a Python framework to work with highthroughput sequencing data. Bioinformatics 31, 166-169.

Arber, S., Han, B., Mendelsohn, M., Smith, M., Jessell, T.M., and Sockanathan, S. (1999). Requirement for the homeobox gene $\mathrm{Hb} 9$ in the consolidation of motor neuron identity. Neuron 23, 659-674.

Bel-Vialar, S., Itasaki, N., and Krumlauf, R. (2002). Initiating Hox gene expression: in the early chick neural tube differential sensitivity to FGF and RA signaling subdivides the HoxB genes in two distinct groups. Development 129, 5103-5115.

Bernstein, E., Duncan, E.M., Masui, O., Gil, J., Heard, E., and Allis, C.D. (2006). Mouse polycomb proteins bind differentially to methylated histone $\mathrm{H} 3$ and RNA and are enriched in facultative heterochromatin. Mol Cell Biol 26, 2560-2569.

Blackledge, N.P., Rose, N.R., and Klose, R.J. (2015). Targeting Polycomb systems to regulate gene expression: modifications to a complex story. Nat Rev Mol Cell Bio 16, 643-649.

Bonev, B., Mendelson Cohen, N., Szabo, Q., Fritsch, L., Papadopoulos, G.L., Lubling, Y., Xu, X., Lv, X., Hugnot, J.P., Tanay, A., et al. (2017). Multiscale 3D Genome Rewiring during Mouse Neural Development. Cell 171, 557-572 e524.

Boyer, L.A., Plath, K., Zeitlinger, J., Brambrink, T., Medeiros, L.A., Lee, T.I., Levine, S.S., Wernig, M., Tajonar, A., Ray, M.K., et al. (2006). Polycomb complexes repress developmental regulators in murine embryonic stem cells. Nature 441, 349-353.

Buenrostro, J.D., Giresi, P.G., Zaba, L.C., Chang, H.Y., and Greenleaf, W.J. (2013).

Transposition of native chromatin for fast and sensitive epigenomic profiling of open chromatin, DNA-binding proteins and nucleosome position. Nat Methods 10, 1213-1218.

Buenrostro, J.D., Wu, B., Chang, H.Y., and Greenleaf, W.J. (2015). ATAC-seq: A Method for Assaying Chromatin Accessibility Genome-Wide. Curr Protoc Mol Biol 109, 2129 21-21 2929.

Bulajic, M., Srivastava, D., Dasen, J.S., Wichterle, H., Mahony, S., and Mazzoni, E.O. (2020). Differential abilities to engage inaccessible chromatin diversify vertebrate Hox binding patterns. Development 147.

Butler, S.J., and Bronner, M.E. (2015). From classical to current: analyzing peripheral nervous system and spinal cord lineage and fate. Dev Biol 398, 135-146.

Cales, C., Roman-Trufero, M., Pavon, L., Serrano, I., Melgar, T., Endoh, M., Perez, C., Koseki, H., and Vidal, M. (2008). Inactivation of the polycomb group protein Ring1B unveils an antiproliferative role in hematopoietic cell expansion and cooperation with tumorigenesis associated with Ink4a deletion. Mol Cell Biol 28, 1018-1028. 
Catela, C., Shin, M.M., Lee, D.H., Liu, J.P., and Dasen, J.S. (2016). Hox Proteins Coordinate Motor Neuron Differentiation and Connectivity Programs through Ret/Gfr alpha Genes. Cell Rep 14, 1901-1915.

Ciabrelli, F., Comoglio, F., Fellous, S., Bonev, B., Ninova, M., Szabo, Q., Xuereb, A., Klopp, C., Aravin, A., Paro, R., et al. (2017). Stable Polycomb-dependent transgenerational inheritance of chromatin states in Drosophila. Nat Genet 49, 876-886.

Coleman, R.T., and Struhl, G. (2017). Causal role for inheritance of H3K27me3 in maintaining the OFF state of a Drosophila HOX gene. Science 356.

Dasen, J.S., De Camilli, A., Wang, B., Tucker, P.W., and Jessell, T.M. (2008). Hox repertoires for motor neuron diversity and connectivity gated by a single accessory factor, FoxP1. Cell 134, 304-316.

Dasen, J.S., Liu, J.P., and Jessell, T.M. (2003). Motor neuron columnar fate imposed by sequential phases of Hox-c activity. Nature 425, 926-933.

Dasen, J.S., Tice, B.C., Brenner-Morton, S., and Jessell, T.M. (2005). A Hox regulatory network establishes motor neuron pool identity and target-muscle connectivity. Cell 123, 477-491.

del Mar Lorente, M., Marcos-Gutierrez, C., Perez, C., Schoorlemmer, J., Ramirez, A., Magin, T., and Vidal, M. (2000). Loss- and gain-of-function mutations show a polycomb group function for Ring1A in mice. Development 127, 5093-5100.

Desanlis, I., Kherdjemil, Y., Mayran, A., Bouklouch, Y., Gentile, C., Sheth, R., Zeller, R., Drouin, J., and Kmita, M. (2020). HOX13-dependent chromatin accessibility underlies the transition towards the digit development program. Nat Commun 11, 2491.

Dessaud, E., Yang, L.L., Hill, K., Cox, B., Ulloa, F., Ribeiro, A., Mynett, A., Novitch, B.G., and Briscoe, J. (2007). Interpretation of the sonic hedgehog morphogen gradient by a temporal adaptation mechanism. Nature 450, 717-720.

Di Meglio, T., Kratochwil, C.F., Vilain, N., Loche, A., Vitobello, A., Yonehara, K., Hrycaj, S.M., Roska, B., Peters, A.H., Eichmann, A., et al. (2013). Ezh2 orchestrates topographic migration and connectivity of mouse precerebellar neurons. Science 339, 204-207.

Dobin, A., Davis, C.A., Schlesinger, F., Drenkow, J., Zaleski, C., Jha, S., Batut, P., Chaisson, M., and Gingeras, T.R. (2013). STAR: ultrafast universal RNA-seq aligner. Bioinformatics 29, $15-21$.

Doe, C.Q. (2017). Temporal Patterning in the Drosophila CNS. Annu Rev Cell Dev Biol 33, 219-240.

Ezhkova, E., Pasolli, H.A., Parker, J.S., Stokes, N., Su, I.H., Hannon, G., Tarakhovsky, A., and Fuchs, E. (2009). Ezh2 orchestrates gene expression for the stepwise differentiation of tissuespecific stem cells. Cell 136, 1122-1135. 
Farcas, A.M., Blackledge, N.P., Sudbery, I., Long, H.K., McGouran, J.F., Rose, N.R., Lee, S., Sims, D., Cerase, A., Sheahan, T.W., et al. (2012). KDM2B links the Polycomb Repressive Complex 1 (PRC1) to recognition of CpG islands. eLife 1, e00205.

Fasano, C.A., Phoenix, T.N., Kokovay, E., Lowry, N., Elkabetz, Y., Dimos, J.T., Lemischka, I.R., Studer, L., and Temple, S. (2009). Bmi-1 cooperates with Foxg1 to maintain neural stem cell self-renewal in the forebrain. Genes Dev 23, 561-574.

Fishell, G., and Kepecs, A. (2020). Interneuron Types as Attractors and Controllers. Annu Rev Neurosci 43, 1-30.

Gao, Z., Zhang, J., Bonasio, R., Strino, F., Sawai, A., Parisi, F., Kluger, Y., and Reinberg, D. (2012). PCGF homologs, CBX proteins, and RYBP define functionally distinct PRC1 family complexes. Mol Cell 45, 344-356.

Gentile, C., Berlivet, S., Mayran, A., Paquette, D., Guerard-Millet, F., Bajon, E., Dostie, J., and Kmita, M. (2019). PRC2-Associated Chromatin Contacts in the Developing Limb Reveal a Possible Mechanism for the Atypical Role of PRC2 in HoxA Gene Expression. Dev Cell 50, 184-196 e184.

Gentile, C., and Kmita, M. (2020). Polycomb Repressive Complexes in Hox Gene Regulation: Silencing and Beyond: The Functional Dynamics of Polycomb Repressive Complexes in Hox Gene Regulation. Bioessays 42, e1900249.

Golden, M.G., and Dasen, J.S. (2012). Polycomb repressive complex 1 activities determine the columnar organization of motor neurons. Genes \& development 26, 2236-2250.

Hanley, O., Zewdu, R., Cohen, L.J., Jung, H., Lacombe, J., Philippidou, P., Lee, D.H., Selleri, L., and Dasen, J.S. (2016). Parallel Pbx-Dependent Pathways Govern the Coalescence and Fate of Motor Columns. Neuron 91, 1005-1020.

Heinz, S., Benner, C., Spann, N., Bertolino, E., Lin, Y.C., Laslo, P., Cheng, J.X., Murre, C., Singh, H., and Glass, C.K. (2010). Simple combinations of lineage-determining transcription factors prime cis-regulatory elements required for macrophage and B cell identities. Mol Cell 38, 576-589.

Hidalgo, I., Herrera-Merchan, A., Ligos, J.M., Carramolino, L., Nunez, J., Martinez, F., Dominguez, O., Torres, M., and Gonzalez, S. (2012). Ezh1 is required for hematopoietic stem cell maintenance and prevents senescence-like cell cycle arrest. Cell Stem Cell 11, 649-662.

Hirabayashi, Y., Suzki, N., Tsuboi, M., Endo, T.A., Toyoda, T., Shinga, J., Koseki, H., Vidal, M., and Gotoh, Y. (2009). Polycomb limits the neurogenic competence of neural precursor cells to promote astrogenic fate transition. Neuron 63, 600-613.

Hisada, K., Sanchez, C., Endo, T.A., Endoh, M., Roman-Trufero, M., Sharif, J., Koseki, H., and Vidal, M. (2012). RYBP represses endogenous retroviruses and preimplantation- and germ linespecific genes in mouse embryonic stem cells. Mol Cell Biol 32, 1139-1149. 
Hobert, O., and Kratsios, P. (2019). Neuronal identity control by terminal selectors in worms, flies, and chordates. Curr Opin Neurobiol 56, 97-105.

Isono, K., Endo, T.A., Ku, M., Yamada, D., Suzuki, R., Sharif, J., Ishikura, T., Toyoda, T., Bernstein, B.E., and Koseki, H. (2013). SAM domain polymerization links subnuclear clustering of PRC1 to gene silencing. Dev Cell 26, 565-577.

Jung, H., Lacombe, J., Mazzoni, E.O., Liem, K.F., Jr., Grinstein, J., Mahony, S., Mukhopadhyay, D., Gifford, D.K., Young, R.A., Anderson, K.V., et al. (2010). Global control of motor neuron topography mediated by the repressive actions of a single hox gene. Neuron 67, 781-796.

Jung, H., Mazzoni, E.O., Soshnikova, N., Hanley, O., Venkatesh, B., Duboule, D., and Dasen, J.S. (2014). Evolving Hox activity profiles govern diversity in locomotor systems. Dev Cell 29, 171-187.

Kicheva, A., Bollenbach, T., Ribeiro, A., Valle, H.P., Lovell-Badge, R., Episkopou, V., and Briscoe, J. (2014). Coordination of progenitor specification and growth in mouse and chick spinal cord. Science 345, 1254927.

Kishi, Y., and Gotoh, Y. (2018). Regulation of Chromatin Structure During Neural Development. Front Neurosci 12, 874.

Langmead, B., and Salzberg, S.L. (2012). Fast gapped-read alignment with Bowtie 2. Nat Methods 9, 357-359.

Liu, J.P., Laufer, E., and Jessell, T.M. (2001). Assigning the positional identity of spinal motor neurons: rostrocaudal patterning of Hox-c expression by FGFs, Gdf11, and retinoids. Neuron 32, 997-1012.

Loker, R., Sanner, J.E., and Mann, R.S. (2021). Ubx orchestrates tissue identity through regional and bidirectional changes to chromatin accessibility. bioRxiv, 2021.2001.2015.426863.

Love, M.I., Huber, W., and Anders, S. (2014). Moderated estimation of fold change and dispersion for RNA-seq data with DESeq2. Genome Biol 15, 550.

Margueron, R., and Reinberg, D. (2011). The Polycomb complex PRC2 and its mark in life. Nature 469, 343-349.

Mazzoni, E.O., Mahony, S., Peljto, M., Patel, P., Thornton, S.R., McCuine, S., Reeder, C., Boyer, L.A., Young, R.A., Gifford, D.K., et al. (2013). Saltatory remodeling of Hox chromatin in response to rostro-caudal patterning signals. Nature Neuroscience In press.

Mendelsohn, A.I., Dasen, J.S., and Jessell, T.M. (2017). Divergent Hox Coding and Evasion of Retinoid Signaling Specifies Motor Neurons Innervating Digit Muscles. Neuron 93, 792-+.

Metzis, V., Steinhauser, S., Pakanavicius, E., Gouti, M., Stamataki, D., Ivanovitch, K., Watson, T., Rayon, T., Mousavy Gharavy, S.N., Lovell-Badge, R., et al. (2018). Nervous System Regionalization Entails Axial Allocation before Neural Differentiation. Cell 175, 1105-1118 e1117. 
Molofsky, A.V., Pardal, R., Iwashita, T., Park, I.K., Clarke, M.F., and Morrison, S.J. (2003). Bmi-1 dependence distinguishes neural stem cell self-renewal from progenitor proliferation. Nature 425, 962-967.

Morey, L., Pascual, G., Cozzuto, L., Roma, G., Wutz, A., Benitah, S.A., and Di Croce, L. (2012). Nonoverlapping functions of the Polycomb group Cbx family of proteins in embryonic stem cells. Cell Stem Cell 10, 47-62.

Narendra, V., Rocha, P.P., An, D., Raviram, R., Skok, J.A., Mazzoni, E.O., and Reinberg, D. (2015). CTCF establishes discrete functional chromatin domains at the Hox clusters during differentiation. Science 347, 1017-1021.

Parker, H.J., and Krumlauf, R. (2020). A Hox gene regulatory network for hindbrain segmentation. Curr Top Dev Biol 139, 169-203.

Philippidou, P., and Dasen, J.S. (2013). Hox genes: choreographers in neural development, architects of circuit organization. Neuron 80, 12-34.

Philippidou, P., Walsh, C.M., Aubin, J., Jeannotte, L., and Dasen, J.S. (2012). Sustained Hox5 gene activity is required for respiratory motor neuron development. Nat Neurosci 15, 1636-1644.

Plys, A.J., Davis, C.P., Kim, J., Rizki, G., Keenen, M.M., Marr, S.K., and Kingston, R.E. (2019). Phase separation of Polycomb-repressive complex 1 is governed by a charged disordered region of CBX2. Genes \& development 33, 799-813.

Quinlan, A.R., and Hall, I.M. (2010). BEDTools: a flexible suite of utilities for comparing genomic features. Bioinformatics 26, 841-842.

Rose, N.R., King, H.W., Blackledge, N.P., Fursova, N.A., Ember, K.J., Fischer, R., Kessler, B.M., and Klose, R.J. (2016). RYBP stimulates PRC1 to shape chromatin-based communication between Polycomb repressive complexes. eLife 5.

Rousso, D.L., Gaber, Z.B., Wellik, D., Morrisey, E.E., and Novitch, B.G. (2008). Coordinated actions of the forkhead protein Foxp1 and Hox proteins in the columnar organization of spinal motor neurons. Neuron 59, 226-240.

Sagner, A., and Briscoe, J. (2019). Establishing neuronal diversity in the spinal cord: a time and a place. Development 146.

Schuettengruber, B., Bourbon, H.M., Di Croce, L., and Cavalli, G. (2017). Genome Regulation by Polycomb and Trithorax: 70 Years and Counting. Cell 171, 34-57.

Shen, X., Liu, Y., Hsu, Y.J., Fujiwara, Y., Kim, J., Mao, X., Yuan, G.C., and Orkin, S.H. (2008). EZH1 mediates methylation on histone H3 lysine 27 and complements EZH2 in maintaining stem cell identity and executing pluripotency. Mol Cell 32, 491-502.

Shirasaki, R., and Pfaff, S.L. (2002). Transcriptional codes and the control of neuronal identity. Annu Rev Neurosci 25, 251-281. 
Simon, J.A., and Kingston, R.E. (2009). Mechanisms of polycomb gene silencing: knowns and unknowns. Nat Rev Mol Cell Biol 10, 697-708.

Snitow, M.E., Li, S., Morley, M.P., Rathi, K., Lu, M.M., Kadzik, R.S., Stewart, K.M., and Morrisey, E.E. (2015). Ezh2 represses the basal cell lineage during lung endoderm development. Development 142, 108-117.

Soshnikova, N., and Duboule, D. (2009). Epigenetic temporal control of mouse Hox genes in vivo. Science 324, 1320-1323.

Struhl, G., and Akam, M. (1985). Altered distributions of Ultrabithorax transcripts in extra sex combs mutant embryos of Drosophila. EMBO J 4, 3259-3264.

Struhl, G., and White, R.A. (1985). Regulation of the Ultrabithorax gene of Drosophila by other bithorax complex genes. Cell 43, 507-519.

Su, I.H., Basavaraj, A., Krutchinsky, A.N., Hobert, O., Ullrich, A., Chait, B.T., and Tarakhovsky, A. (2003). Ezh2 controls B cell development through histone H3 methylation and Igh rearrangement. Nat Immunol 4, 124-131.

Takashima, Y., Era, T., Nakao, K., Kondo, S., Kasuga, M., Smith, A.G., and Nishikawa, S. (2007). Neuroepithelial cells supply an initial transient wave of MSC differentiation. Cell 129, 1377-1388.

Tavares, L., Dimitrova, E., Oxley, D., Webster, J., Poot, R., Demmers, J., Bezstarosti, K., Taylor, S., Ura, H., Koide, H., et al. (2012). RYBP-PRC1 complexes mediate H2A ubiquitylation at polycomb target sites independently of PRC2 and H3K27me3. Cell 148, 664-678.

Tsuboi, M., Kishi, Y., Yokozeki, W., Koseki, H., Hirabayashi, Y., and Gotoh, Y. (2018). Ubiquitination-Independent Repression of PRC1 Targets during Neuronal Fate Restriction in the Developing Mouse Neocortex. Dev Cell 47, 758-772 e755.

Tursun, B., Patel, T., Kratsios, P., and Hobert, O. (2011). Direct conversion of C. elegans germ cells into specific neuron types. Science 331, 304-308.

Venkatasubramanian, L., and Mann, R.S. (2019). The development and assembly of the Drosophila adult ventral nerve cord. Curr Opin Neurobiol 56, 135-143.

von Schimmelmann, M., Feinberg, P.A., Sullivan, J.M., Ku, S.M., Badimon, A., Duff, M.K., Wang, Z., Lachmann, A., Dewell, S., Ma'ayan, A., et al. (2016). Polycomb repressive complex 2 (PRC2) silences genes responsible for neurodegeneration. Nat Neurosci 19, 1321-1330.

Wang, R., Taylor, A.B., Leal, B.Z., Chadwell, L.V., Ilangovan, U., Robinson, A.K., Schirf, V., Hart, P.J., Lafer, E.M., Demeler, B., et al. (2010). Polycomb group targeting through different binding partners of RING1B C-terminal domain. Structure 18, 966-975.

Wang, W., Cho, H., Kim, D., Park, Y., Moon, J.H., Lim, S.J., Yoon, S.M., McCane, M., Aicher, S.A., Kim, S., et al. (2020). PRC2 Acts as a Critical Timer That Drives Oligodendrocyte Fate over Astrocyte Identity by Repressing the Notch Pathway. Cell Rep 32, 108147. 
841 Wilcock, A.C., Swedlow, J.R., and Storey, K.G. (2007). Mitotic spindle orientation distinguishes 842 stem cell and terminal modes of neuron production in the early spinal cord. Development 134 , 843 1943-1954.

844 Yaghmaeian Salmani, B., Monedero Cobeta, I., Rakar, J., Bauer, S., Curt, J.R., Starkenberg, A., 845 and Thor, S. (2018). Evolutionarily conserved anterior expansion of the central nervous system 846 promoted by a common PcG-Hox program. Development 145.

847 Yu, G., Wang, L.G., Han, Y., and He, Q.Y. (2012). clusterProfiler: an R package for comparing 848 biological themes among gene clusters. OMICS 16, 284-287.

849 Yu, G., Wang, L.G., and He, Q.Y. (2015). ChIPseeker: an R/Bioconductor package for ChIP 850 peak annotation, comparison and visualization. Bioinformatics 31, 2382-2383.

851 Zhang, Y., Liu, T., Meyer, C.A., Eeckhoute, J., Johnson, D.S., Bernstein, B.E., Nusbaum, C., 852 Myers, R.M., Brown, M., Li, W., et al. (2008). Model-based analysis of ChIP-Seq (MACS). 853 Genome Biol 9, R137. 

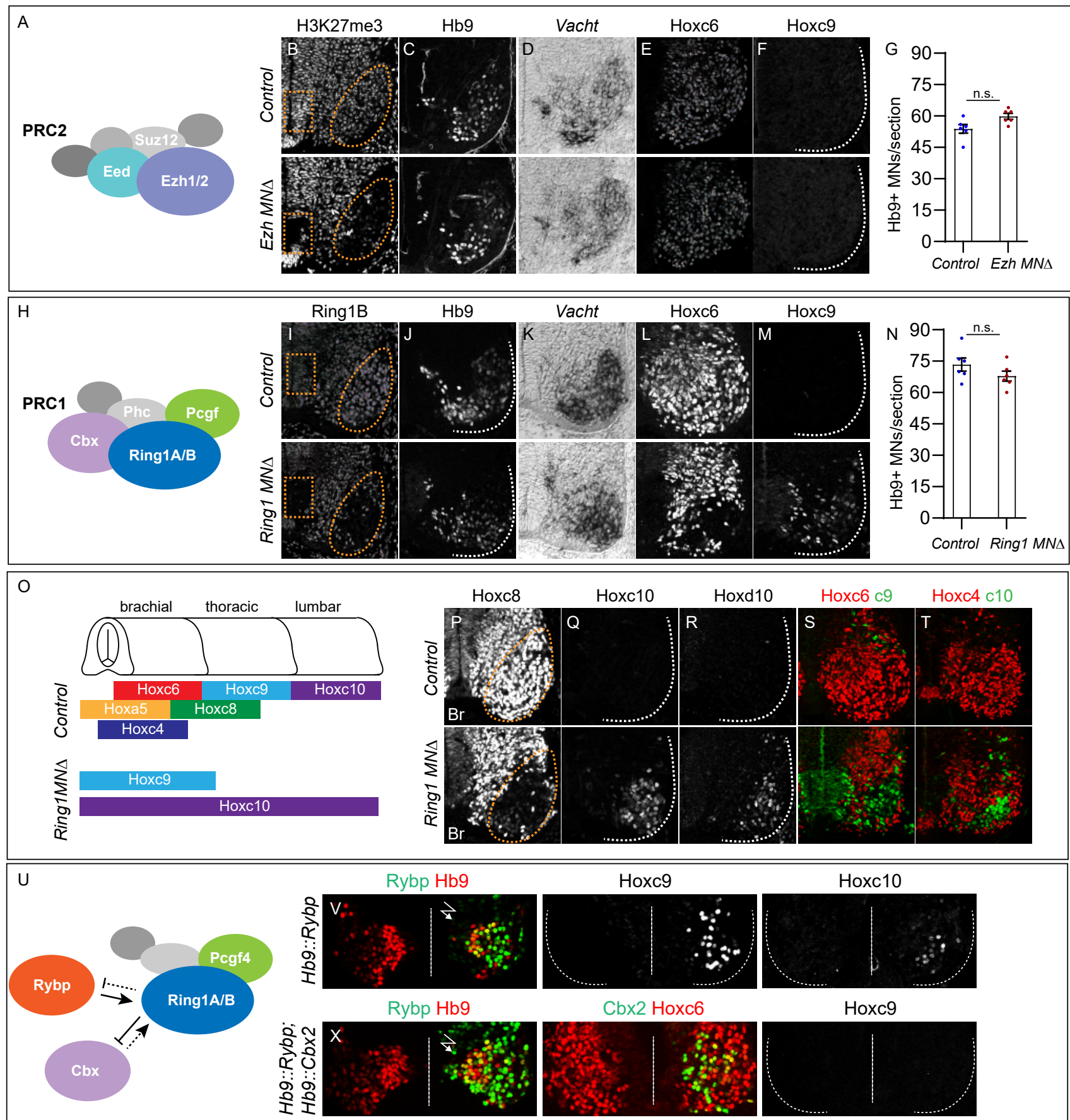
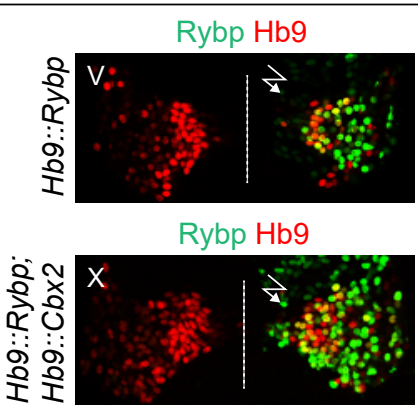

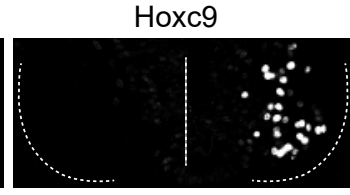

Cbx2 Hoxc6

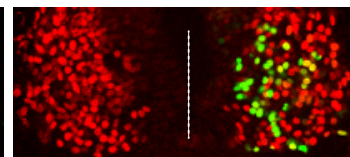

Hoxc10

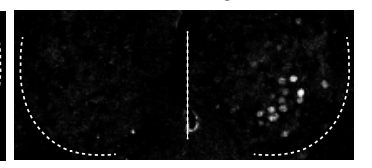

Hoxc9

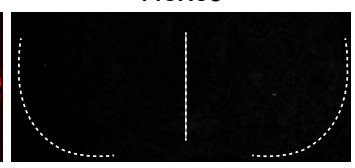

Figure 1. Roles of PRC1 and PRC2 in determining of Hox expression in spinal MNs.

(A) Core components of PRC2. (B) Brachial spinal sections showing H3K27me3 is depleted from progenitors (boxed region) and post-mitotic MNs (oval) in E11.5 Ezh ${ }^{M N \Delta}$ (Ezh1floxflox; Ezh2 floxflox, Olig2::Cre/+) embryos. (C-D) MNs express Hb9 and Vacht in Ezh $h^{M N \Delta}$ mice. (E-F) Brachial Hoxc6 expression is normal in EzhMNA mice, and no ectopic Hoxc9 is detected. (G) Quantification of MNs: $54+/-2 \mathrm{Hb9}^{+}$MNs per section in brachial controls, versus $60+/-1$ in Ezh $h^{M N \Delta}$ mice, $n=6$ sections, $p=0.0696$. $(H)$ Core components of PRC1. (I) Ring1B is selectively removed from progenitors (boxed region) and post-mitotic MNs (oval) in E12.5 Ring $1^{M N \Delta}$ (Ring1A ${ }^{-/}$; Ring1B flox/flox, Olig2::Cre ${ }^{++}$) mice. (J-K) Ring $1^{M N \Delta}$ mice express Hb9 and Vacht. (L-M) Hoxc6 is lost from brachial MNs and Hoxc9 is ectopically expressed in Ring $1^{M N \Delta}$ mice. (N) Quantification of MNs: $73+/-3 \mathrm{Hb} 9^{+} \mathrm{MNs}$ in controls, versus $68+/-2$ in Ring $1^{M N \Delta}$ mice, $n=6$ sections, $\mathrm{p}=0.0956$. (O) Summary of changes in Hox expression in MNs of Ring $1^{M N \Delta}$ mice. (P-R) Loss of Hoxc8 and ectopic Hoxc10 and Hoxd10 expression in brachial MNs in Ring $1^{M N \Delta}$ mice. (S-T) Colabeling of Hoxc6/Hoxc9 and Hoxc4/Hoxc10 in Ring $1^{M N \Delta}$ mice, showing ectopically expressed caudal Hox proteins in place of rostral Hox protein expression in brachial segments. (U) Schematic of Cbx and Rybp interactions in PRC1. (V) Misexpression of Rybp in postmitotic MNs under $\mathrm{Hb} 9$ in chick leads to ectopic Hoxc9 and Hoxc10 expression in brachial MNs. Bolt symbol indicates electroporated side of spinal cord. (X) Co-expression of Rybp and Cbx fails to induce Hoxc9 in brachial MNs. Panels B-F show brachial sections from E11.5 embryos; I-M, P-T brachial sections from E12.5 embryos; V,X brachial chick sections at HH st25. See also Supplementary Figure 1. 

available under aCC-BY 4.0 International license.
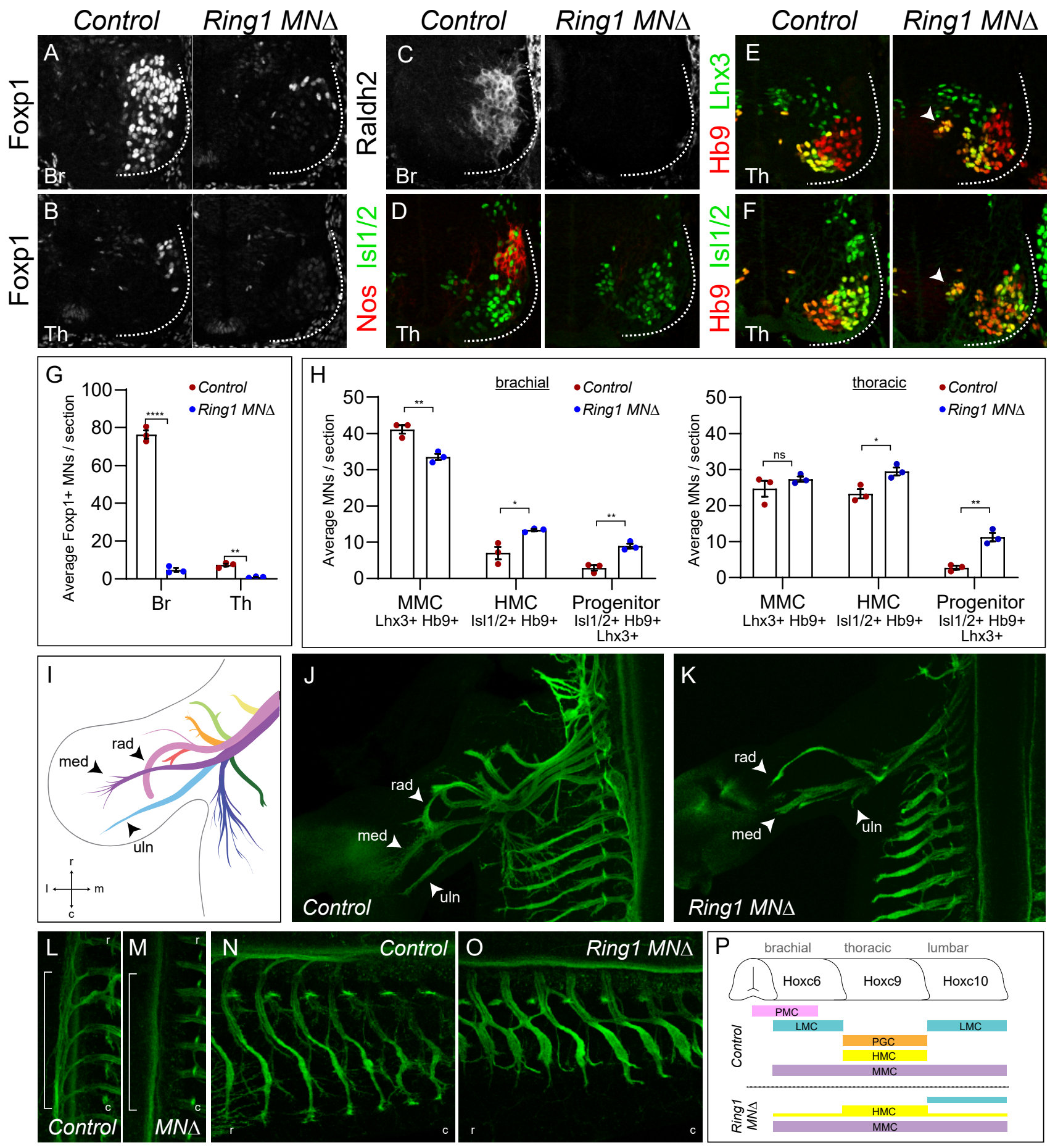

Figure 2. Ring1 is essential for the specification of Hox-dependent MN subtypes.

(A-B) Foxp1 expression is reduced in brachial (Br) and thoracic (Th) segments of Ring $1^{M N \Delta}$ mice at E12.5. (C-D) Expression of the brachial LMC marker Raldh2 and thoracic PGC marker nNos were lost in Ring $1^{\text {MNA }}$ mice. (E-F) Staining of $\mathrm{Hb9}^{+}$, Lhx3 ${ }^{+}$ (MMC) and $\mathrm{Hb} 9$, Is $11 / 2^{+}(\mathrm{HMC})$ neurons. In Ring ${ }^{\mathrm{MN}}$ mice, we also observed a population of medial neurons that coexpressed Isl1/2, Hb9, and Lhx3 (indicated by arrow heads). (G) Quantification of Foxp1 reduction. (H) Quantification of MMC (Hb9 ${ }^{+}$,

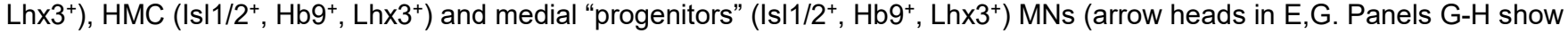
average from $n=3$ mice, 4 sections each animal. Data shown in graphs shown as mean \pm SEM. ${ }^{*} p<0.05,{ }^{* *} p<0.01,{ }^{* * *} p<0.0001$. (I) Schematic of nine primary nerves in E12.5 mouse forelimb (Adapted from Catela et al., 2016) med=median, rad=radial, uln=ulnar nerves. Rostral $(\mathrm{r})$, caudal $(\mathrm{c})$, medial $(\mathrm{m})$, and lateral (I) orientation shown. (J-K) Forelimb motor axons of an E12.5 control and Ring $1^{M N \Delta}$ mouse labeled by Hb9::GFP. (L-M) Innervation of sympathetic chain ganglia (from PGC neurons) in control and Ring $1^{M N \Delta}$ mice. Bracket shows region of PGC projections along rostrocaudal axis. (N-O) Innervation of dorsal and ventral axial muscles by MMC and HMC respectively. In Ring1 $1^{M N \Delta}$ mice, axial motor projections are shorter and thicker. (P) Summary of MN columnar organization of control and Ring $1^{\mathrm{MN} \Delta}$ mice. See also Supplementary Figure 2. 
bioRxiv preprint doi: https://doi.org/10.1101/2021.08.09.455667; this version posted August 11, 2021. The copyright holder for this preprint (which was not certified by peer review) is the author/funder, who has granted bioRxiv a license to display the preprint in perpetuity. It is made available under aCC-BY 4.0 International license.

A
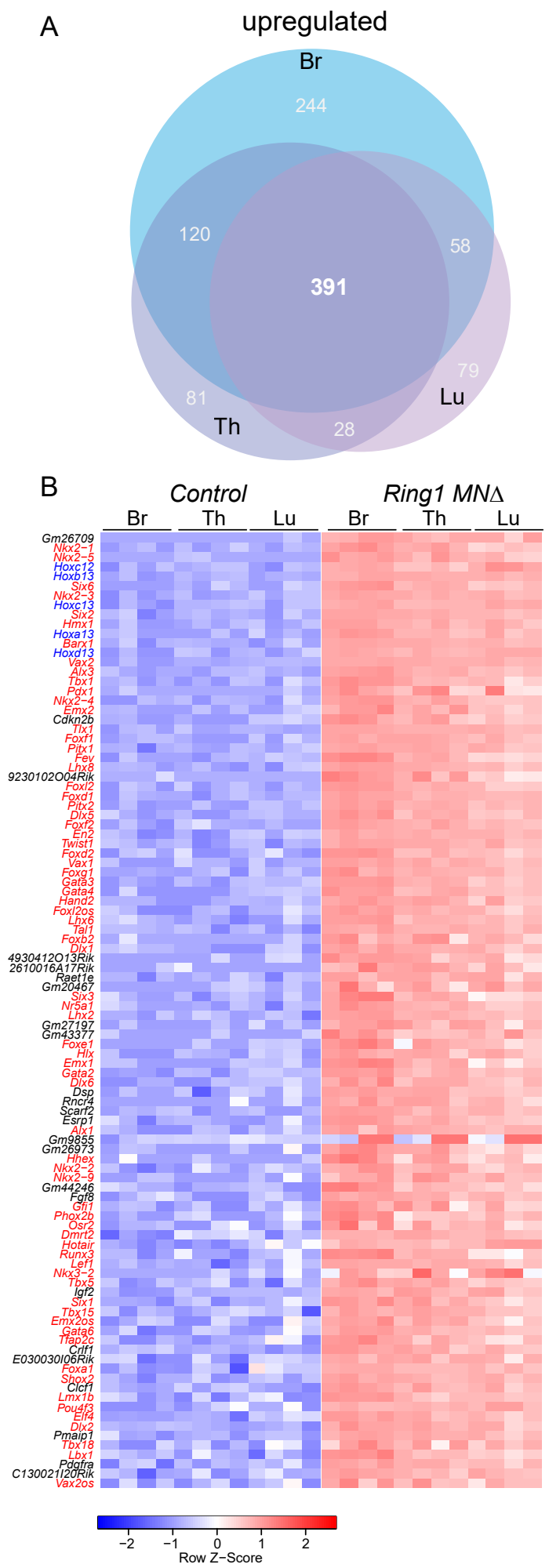
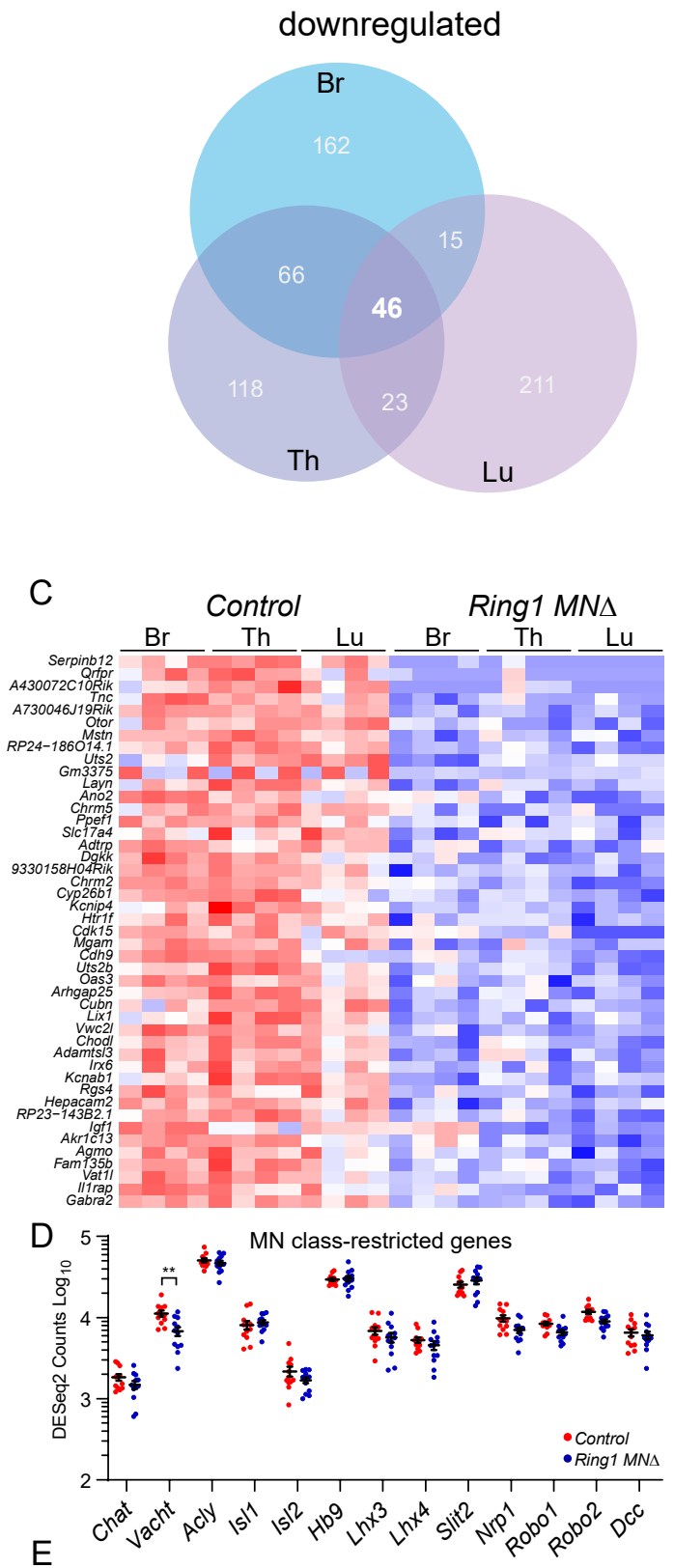

E

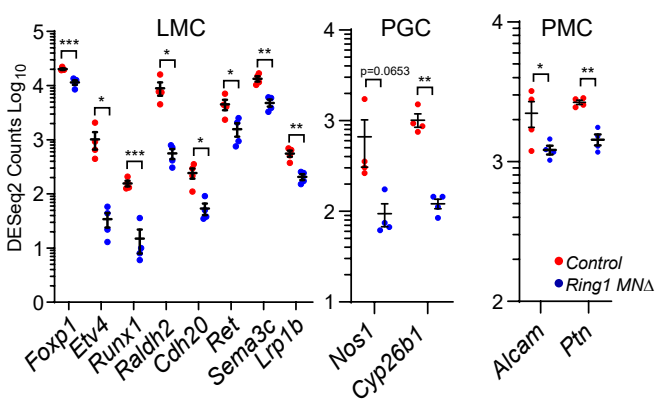

Figure 3. Ring1 is required to restrict transcription factor expression in spinal MNs.

(A) Venn diagrams showing the number of upregulated (left) and downregulated (right) genes in bracial (Br), thoracic (Th), and lumbar (Lu) MNs upon loss of Ring1 from MNs by RNAseq ( $\log _{2}-\mathrm{FC}>2$, FDR<0.1). (B) Heat map of top 100 upregulated genes (by log2-FC) in Ring $1^{M N \Delta}$ mice and control MNs. Genes shown in blue are Hox genes and other transcription factor are shown in red. (C) Heat map of 45 genes downregulated in Ring $1^{M N \Delta}$ mice in comparison to control MNs. (D) Plots of DESeq2 counts of genes associated with MN class identity. Each data point shows DESeq2 counts for each sample, and segment-specific counts are plotted together. Expression of S/c18a3 (Vacht) is reduced (padj. $=0.026477$ ) in Ring1MNA . (E) DESeq2 counts of genes associated with specific MN subtype identities were reduced in Ring $1^{M N \Delta}$ mice. Counts for LMC and PMC markers are from $\mathrm{Br}$ segments, PGC from Th segments. Black bars shown in graphs indicate mean \pm SEM. ${ }^{*} p<0.05,{ }^{* *} p<0.01,{ }^{* * *} p<0.001$, ${ }^{* * * *} p<0.0001$. See also Supplementary Figure 3. 


\section{upregulated}
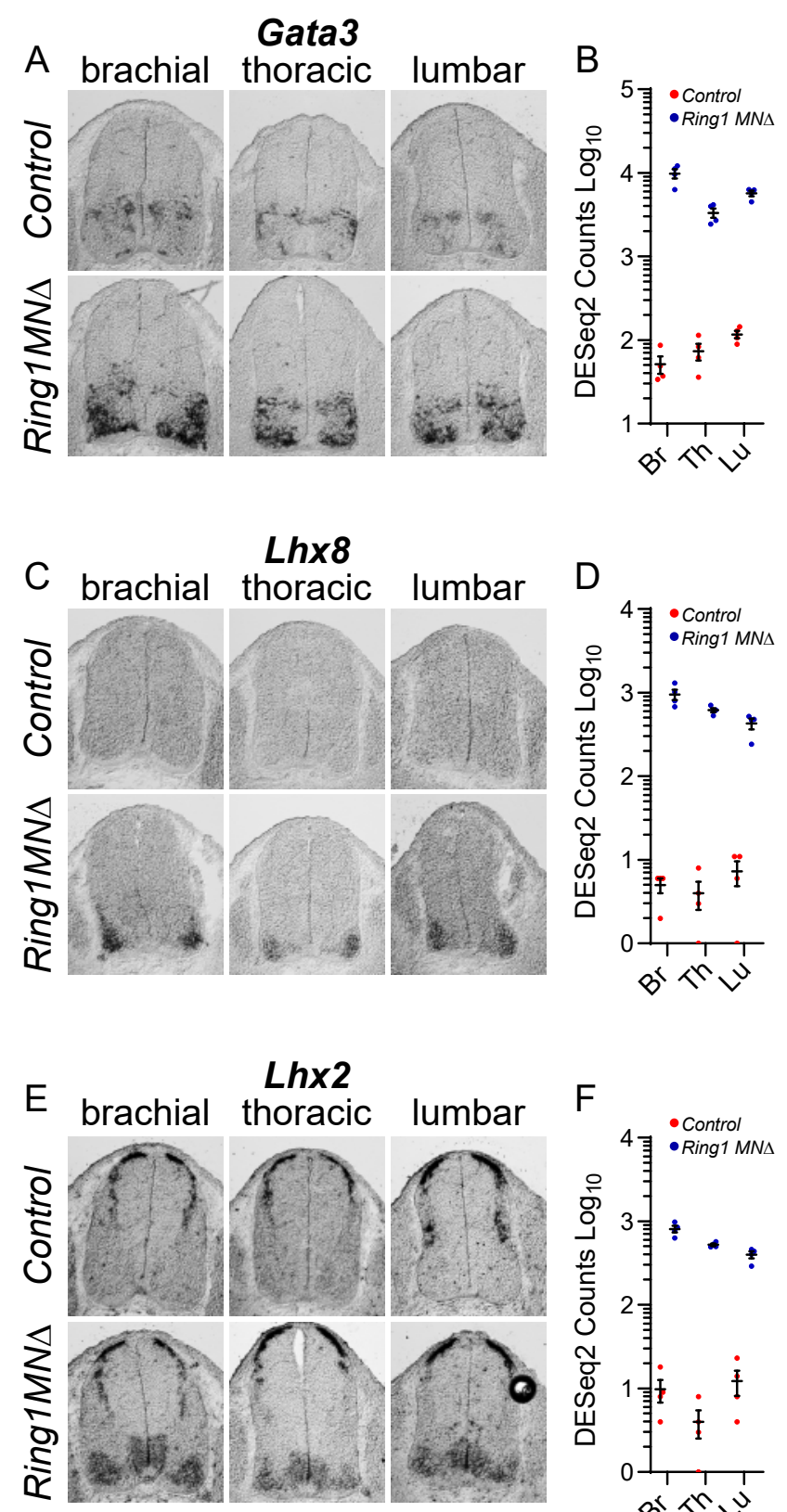
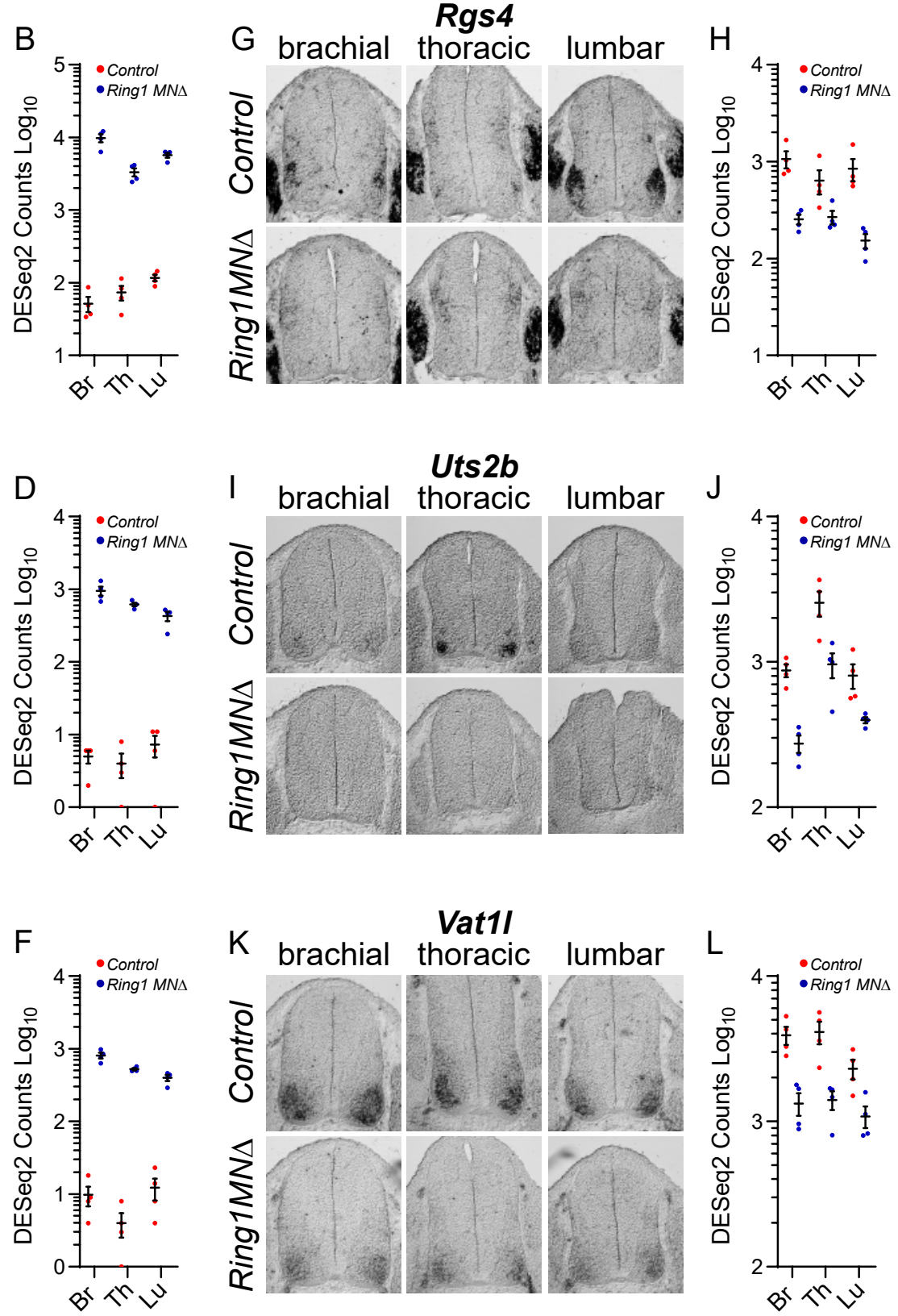

\section{downregulated}

Rgs4

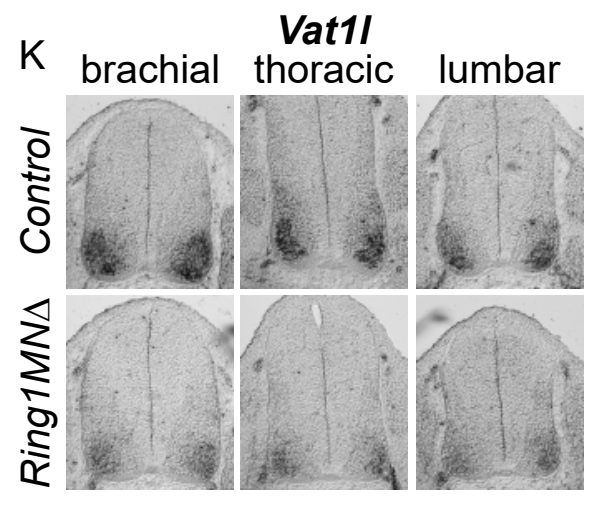

Figure 4. Analyses of misregulated genes in Ring1 mutants.

$(\mathrm{A}, \mathrm{C}, \mathrm{E})$ In situ mRNA hybridization of selected upregulated genes from Ring ${ }^{M N A}$ RNAseq. Images show sections of brachial, thoracic, and lumbar segments from E12.5 control and Ring $1^{M N \Delta}$ mice. (B,D,F) Graphs of DESeq2 counts for each upregulated gene in each segment. Data points show DESeq2 counts from MNs of individual animals from indicated segments. (G, I, K) Analysis of downregulated genes by in situ hybridization. Rgs4 and Uts $2 b$ displayed elevated expression in specific segmental levels in controls, suggesting that a subset of the commonly-downregulated genes are also Hox-dependent. Rgs4 expression is normally elevated in LMC neurons (panel G), while Uts $2 b$ is elevated in thoracic segments of controls (panel I) (H,J,L) Graphs of DESeq2 counts for each downregulated gene in each segment. See also Supplementary Figure 4. 
bioRxiv preprint doi: https://doi.org/10.1101/2021.08.09.455667; this version posted August 11, 2021. The copyright holder for this preprint (which was not certified by peer review) is the author/funder, who has granted bioRxiv a license to display the preprint in perpetuity. It is made available under aCC-BY 4.0 International license.

A

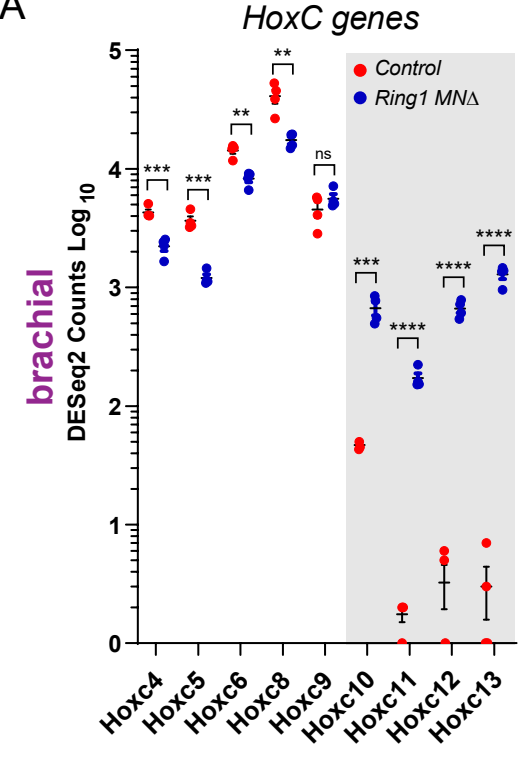

HoxA genes

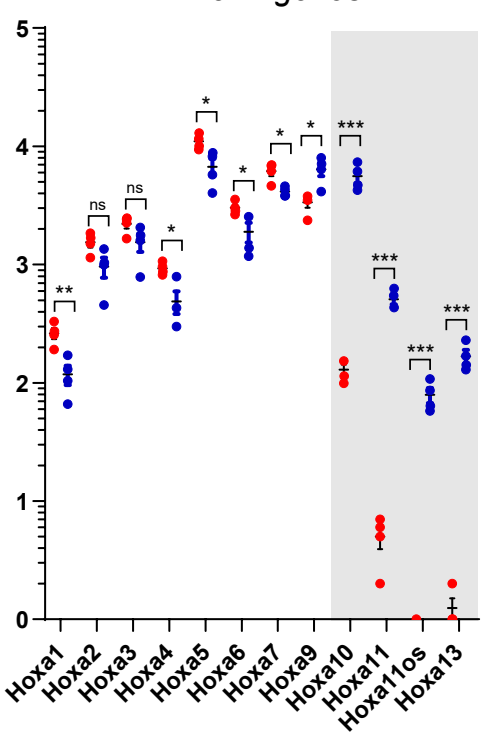

HoxB genes

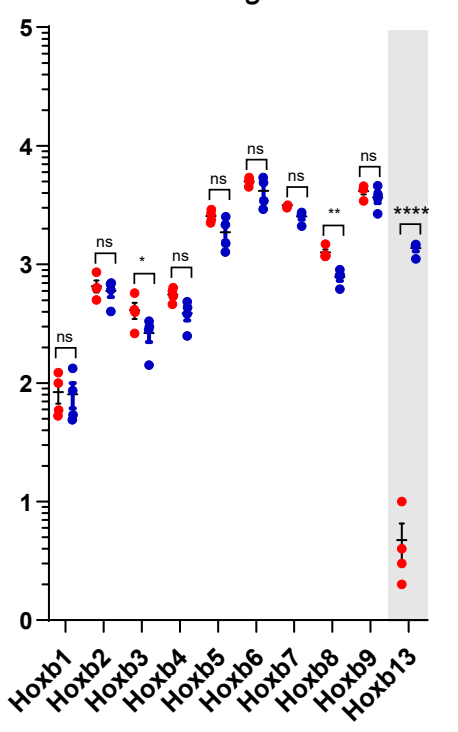

B

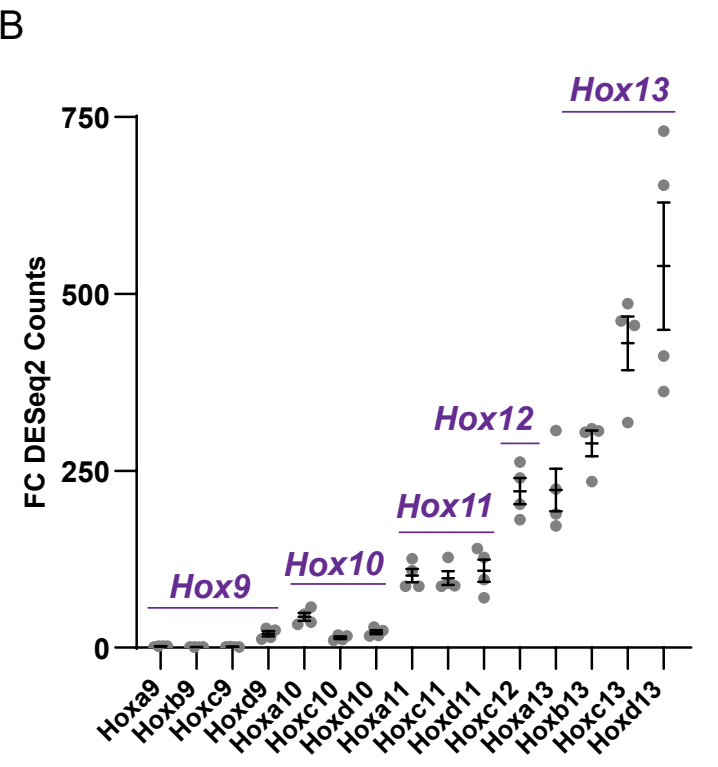

C brachial thoracic lumbar sacral
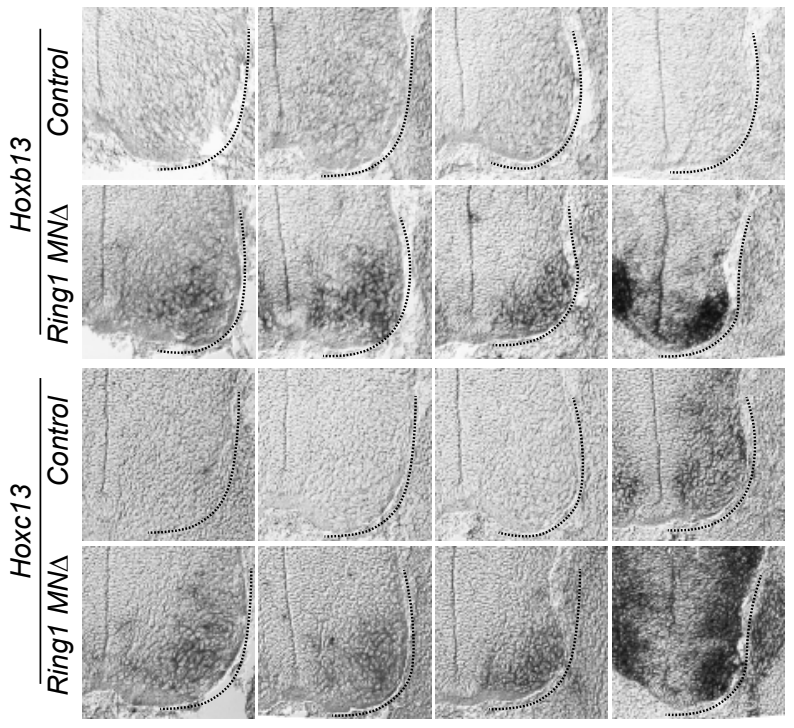

Figure 5. Derepression of caudal Hox genes in Ring1 mutants.

(A) DESeq2 counts of $\operatorname{HoxC}, \operatorname{HoxA}$, and HoxB cluster genes in brachial segments in control and Ring $1^{M N \Delta}$ mice showing derepression of caudal Hox genes. Grey shaded regions highlight Hox genes that are derepressed in Ring 1 MNA mice. Hoxc 9 does not show significant derepression, likely because it is normally expressed by caudal brachial MNs. Black bars shown in graphs indicate mean \pm SEM. ${ }^{*} p<0.05,{ }^{* *} p<0.01,{ }^{* * *} p<0.001,{ }^{* * * *} p<0.0001$. (B) Comparison of Hox9-Hox13 paralog gene derepression in brachial segments. Graph shows absolute fold changes of DESeq2 counts, showing a marked increase for caudal Hox13 paralogs in Ring $1^{M N \Delta}$ mice. Each data point shows individual counts for Ring1 mutants/average of controls. (C) In situ of Hoxb13 and Hoxc13 mRNA transcripts in E12.5 embryos. Hoxb13 is normally not detectable in spinal cord, but is derepressed in MNs in Ring $1^{M N \Delta}$ mice. Hoxc13 transcripts are normally restricted to sacral segments but derepressed in rostral segments in Ring $1^{M N \Delta}$ mice. See also Supplementary Figure 5. 

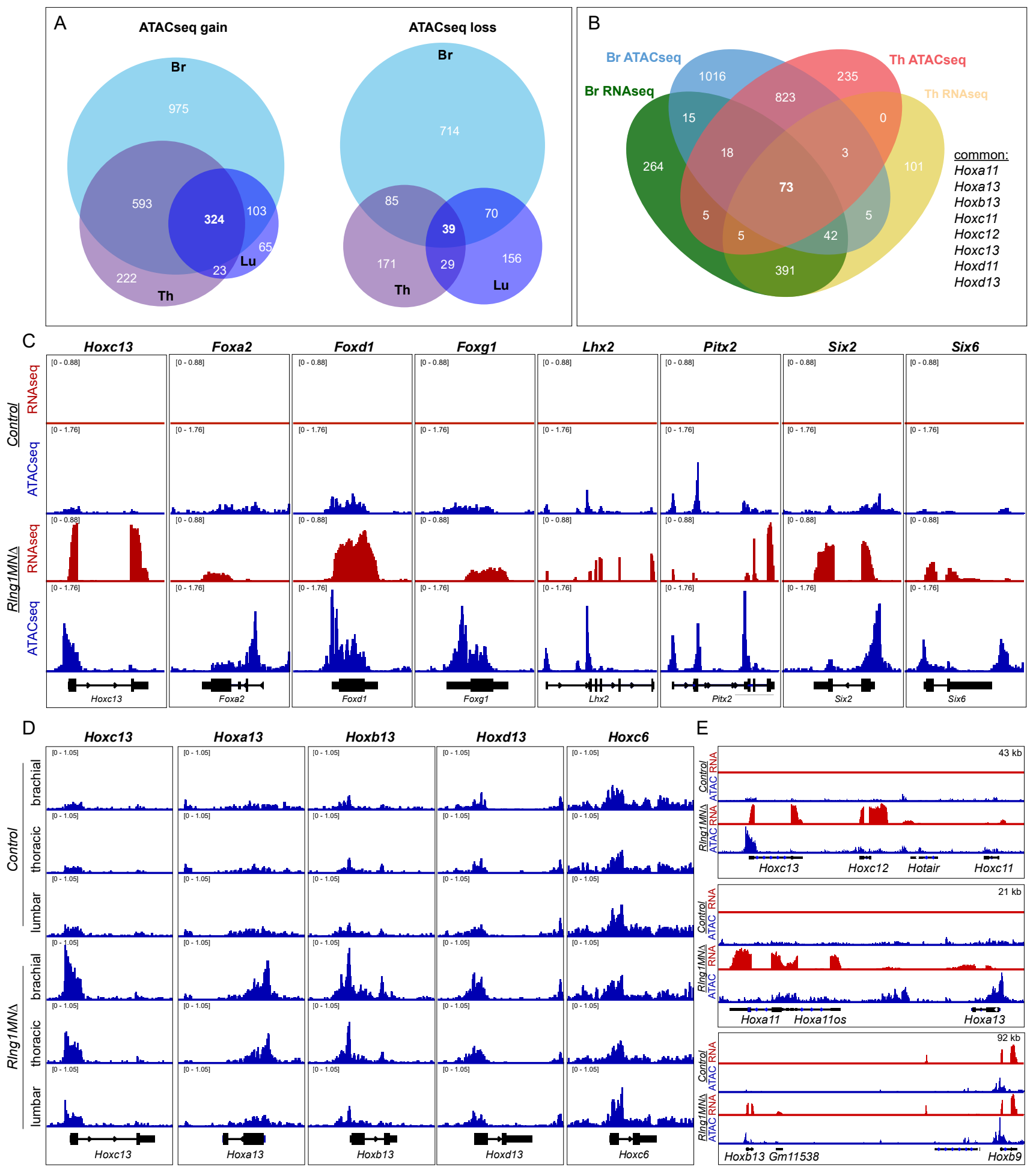

$\mathrm{E}$

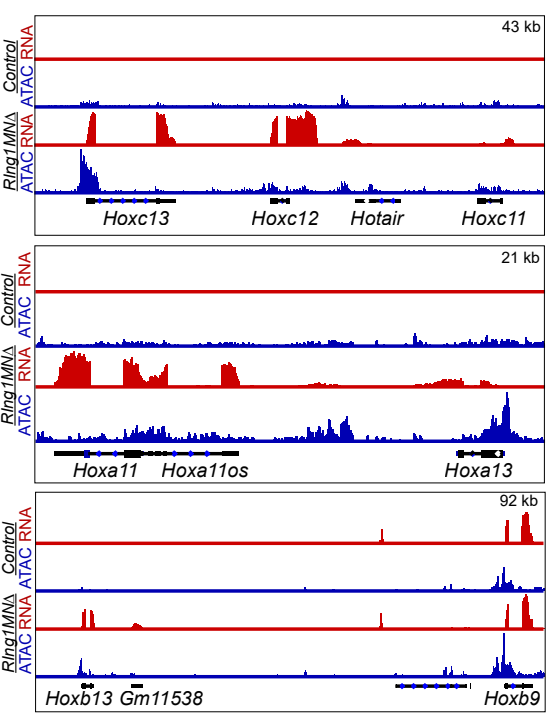

Figure 6. Ring1 is essential for maintaining chromatin topology of cell fate determinants.

(A) Proportional Venn diagram showing the number of genes that gain (left) or lose (right) chromatin accessibility in brachial, thoracic and lumbar segments in Ring $1^{M N \Delta}$ mice. (B) Venn diagram of upregulated genes from RNAseq and genes that gained accessibility in ATACseq of brachial and thoracic segments. (C) IGV browser views of selected genes that are upregulated and gained chromatin accessibility in controls and Ring $1^{M N \Delta}$ mice in brachial segments. (D) IGV browser views of ATACseq tracks in controls and Ring $1^{M N \Delta}$ mice in brachial, thoracic, and lumbar segments. Hox 13 genes gain chromatin accessibility in each segment, while reduced brachial Hoxc6 expression is not associated with a loss of chromatin accessibility. (E) Comparison of IGV browser views of RNAseq and ATACseq tracks of caudal HoxC, HoxA and HoxB genes in brachial segments. See also Supplementary Figure 6. 

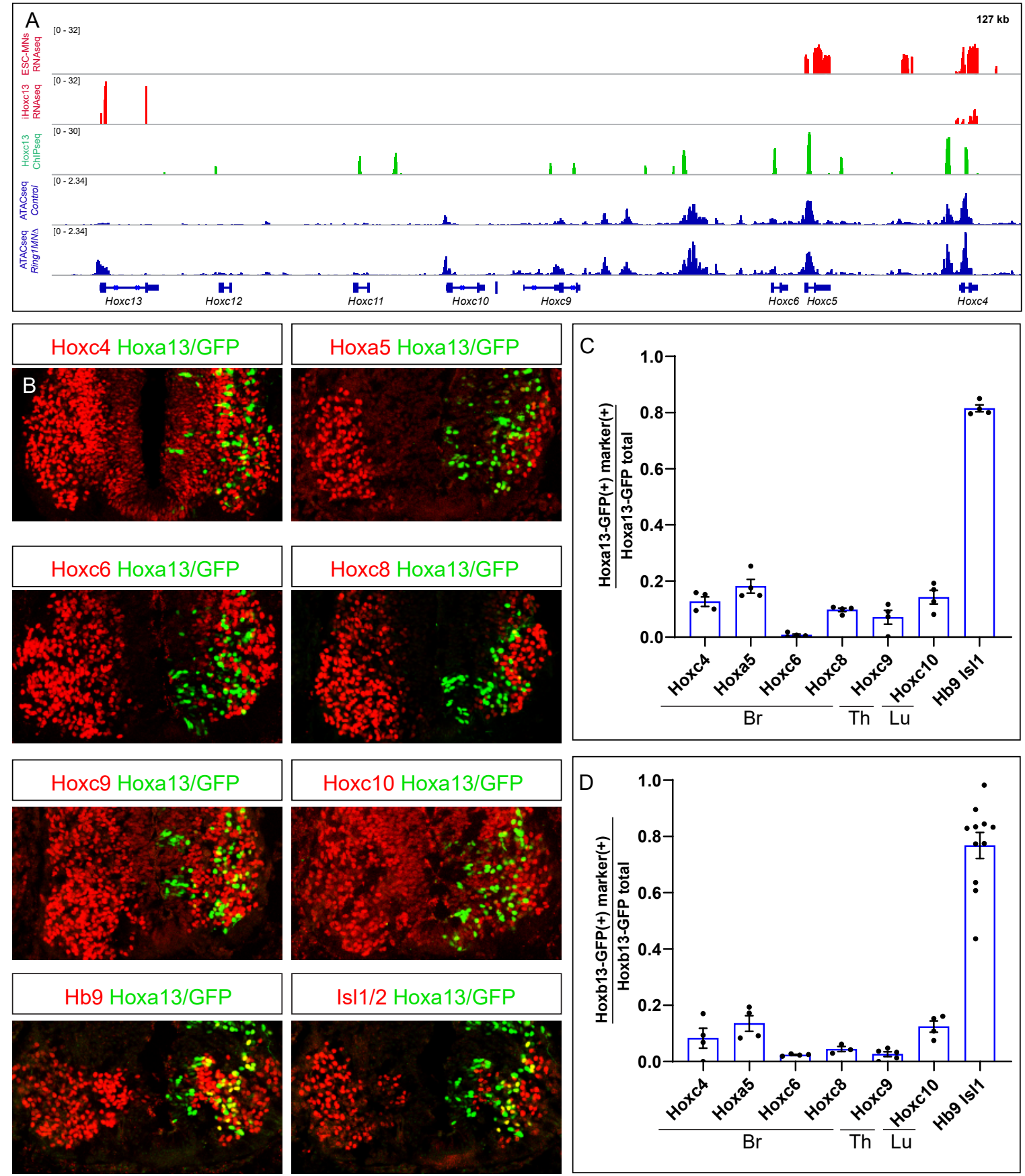

IsI1/2 Hoxa13/GFP
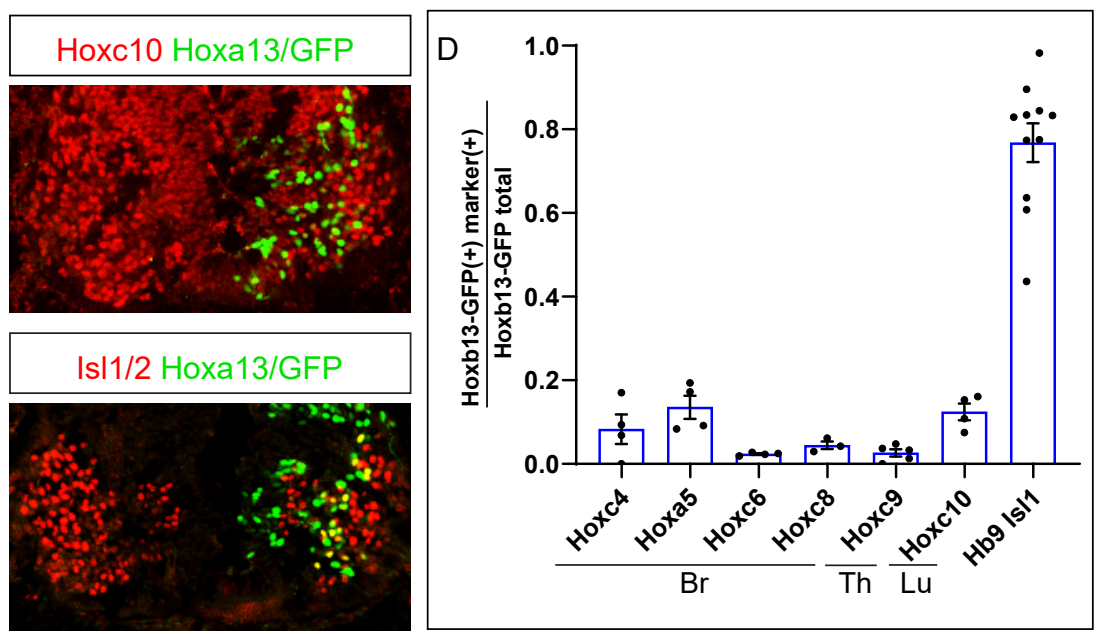

Figure 7. Hox13 proteins repress multiple Hox4-Hox10 paralogs.

(A) Effects of Hoxc13 induction in ESC-MNs. Top panels show IGV browser views (log scale) of RNAseq (red) and ChIPseq tracks (green) at the HoxC cluster. Induced Hoxc13 binds near multiple HoxC genes and represses expression of Hoxc4 and Hoxc5. Bottom panels show ATACseq in brachial control and Ring1 mutant MNs at the HoxC cluster (blue). (B) Misexpression of $m$ Hoxa13-ires-nucGFP represses more rostral Hox genes. Hoxc4, Hoxa5, Hoxc6 and Hoxc8 were analyzed in brachial segments, Hoxc9 in thoracic segments, and Hoxc10 in lumbar segments. Hb9 and Isl1 images are from brachial segments. (C,D) Quantification of percentage of electroporated cells which retained the expression of indicated Hox protein and MN markers upon Hoxa13 or Hoxb13 misexpression. Quantified electroporated cells were selected from the ventrolateral spinal cord, where MNs reside. $\mathrm{Hb} 9$ and IsI1/2 quantification shows percentage of $\mathrm{GFP}^{+}$neurons that express either marker, and are shown for $\mathrm{Br}$ segments in panel $\mathrm{B}$, and $\mathrm{Br}$ and Th segments in $\mathrm{C}$. Data in graphs shown as mean $\pm \mathrm{SEM}$, averaged from $\mathrm{n}=3$ animals, 4 sections each. See also Supplementary Figure 7. 
bioRxiv preprint doi: https://doi.org/10.1101/2021.08.09.455667; this version posted August 11, 2021. The copyright holder for this preprint (which was not certified by peer review) is the author/funder, who has granted bioRxiv a license to display the preprint in perpetuity. It is made available under aCC-BY 4.0 International license.

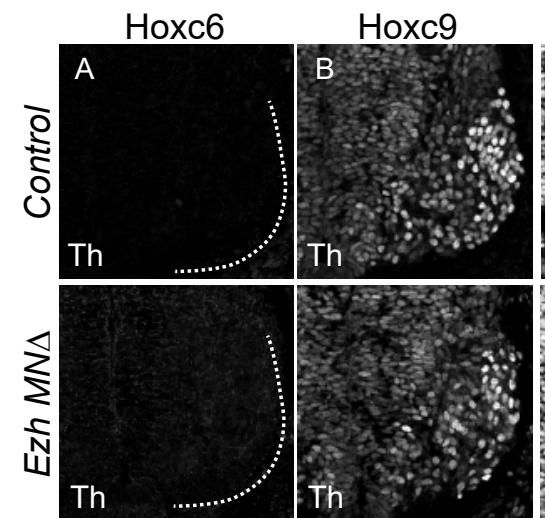

Hoxc6
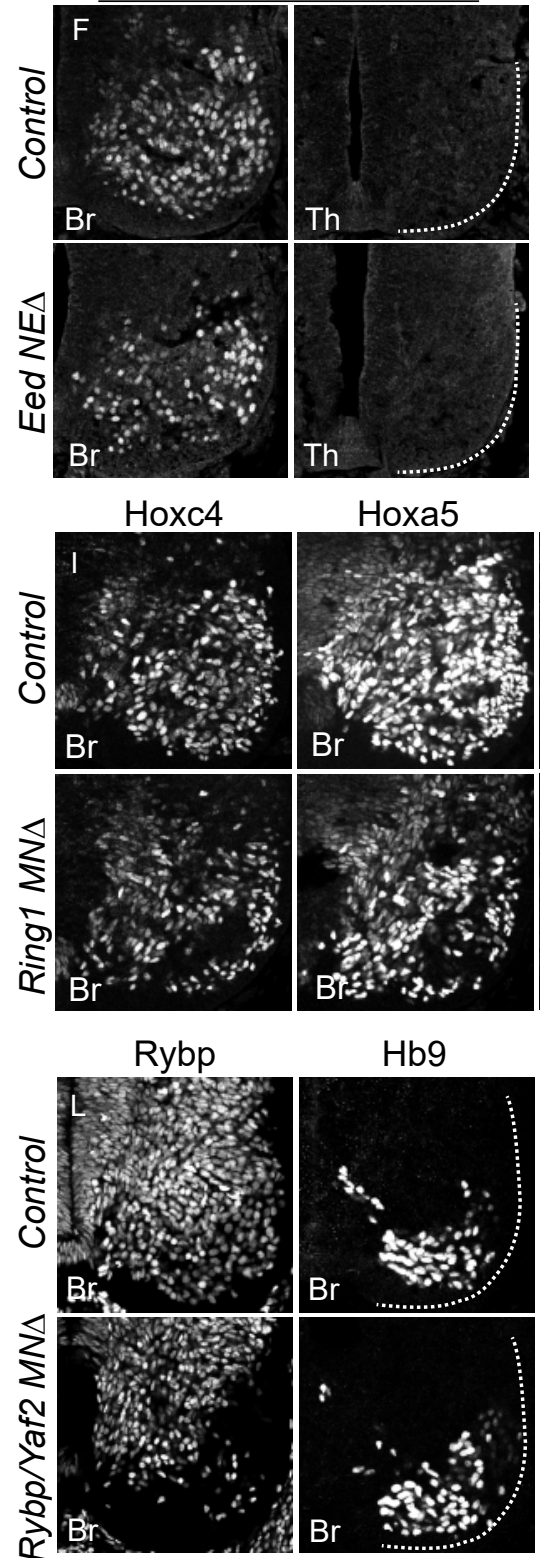

$\mathrm{Hb} 9$

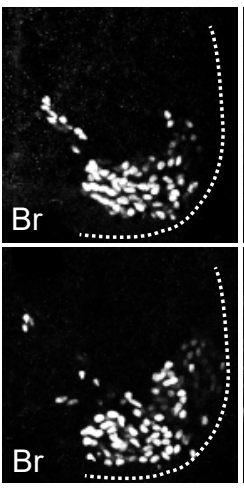

Hoxc10

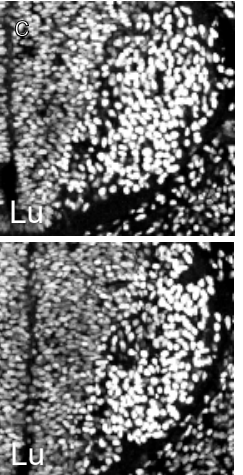

L

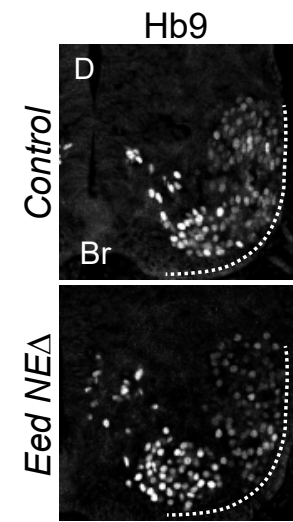

Hoxc9

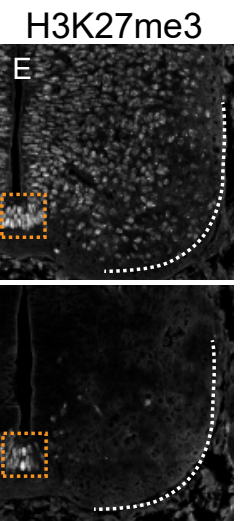

Hoxc10
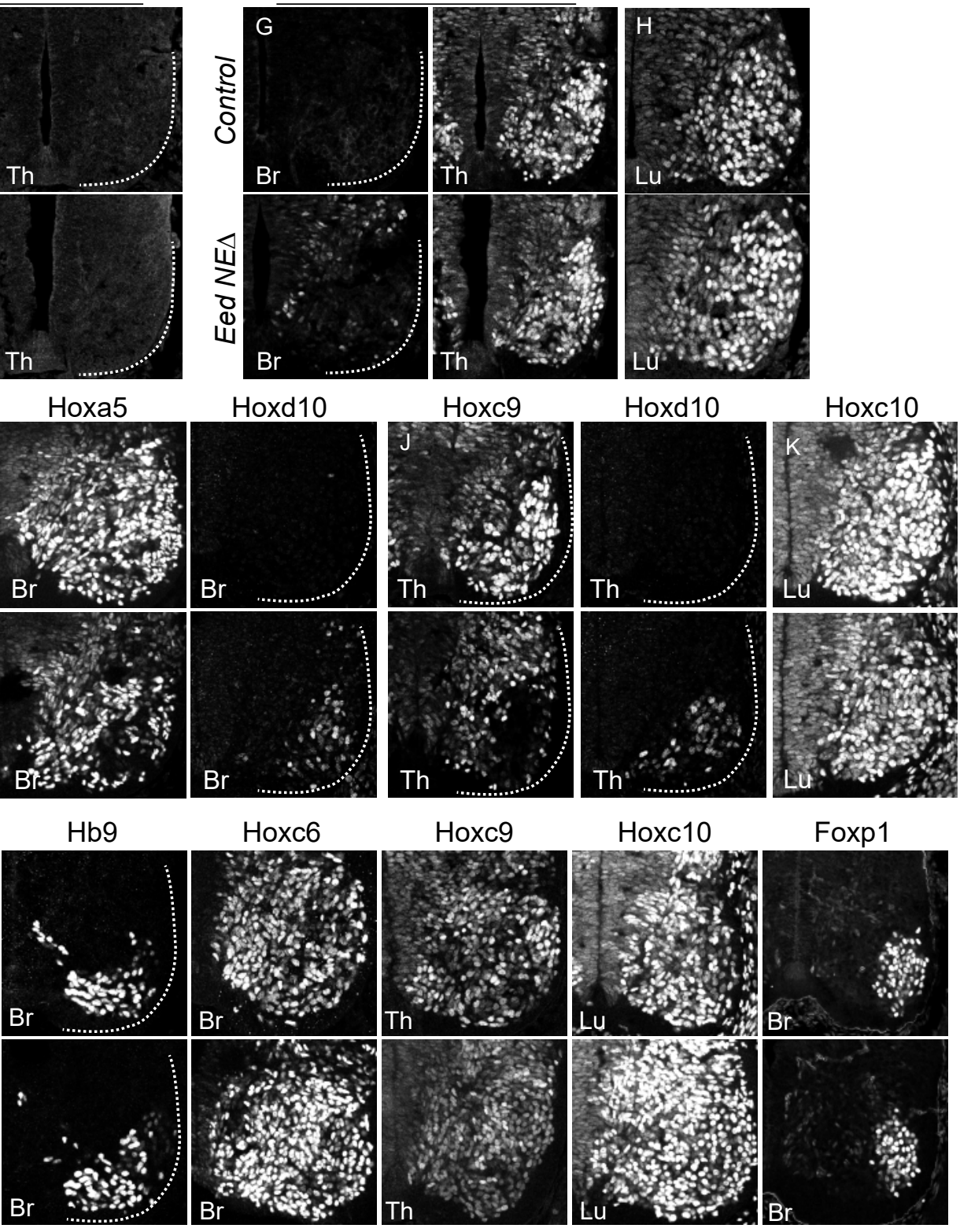

Supplementary Figure 1. Effects of PRC mutations on MN differentiation.

(A-C) Expression of Hoxc9 in thoracic segments and Hoxc10 in lumbar segments is normal in E11.5 Ezh ${ }^{M N \Delta}$ mice (Eed floxflox, Sox $1:: \mathrm{Cre}^{++}$), and no ectopic thoracic Hoxc6 expression is detected. (D,E) In Eed ${ }^{N E \Delta}$ mice (H3K27me3 is depleted throughout the spinal cord at E12.5, while $\mathrm{Hb} 9$ expression is unaffected. Some H3K27me3 is detected in the floor plate of Eed ${ }^{N E \Delta}$ mice (boxed region). (F-H) Brachial Hoxc6, thoracic Hoxc9, and lumbar Hoxc10 are detected normally in Eed ${ }^{N E \Delta}$ mice. (I) Brachial Hoxc4 and Hoxa5 are lost from MNs in Ring $1^{M N \Delta}$ mice, and Hoxd10 is ectopically expressed in brachial MNs. (J) Hoxc9 expression is reduced in thoracic segments of Ring $1^{M N \Delta}$ mice, and Hoxd10 is expressed. (K) Expression of Hoxc10 is retained at lumber levels of Ring $1^{M N \Delta}$ mice. (L) Analysis of E12.5 Rybp/Yaf2 ${ }^{M N \Delta}$ mice $\left(\right.$ Rybp floxflox; Yaf2 $^{-/}$; Olig2::Cre $\left.{ }^{/+}\right)$. Rybp expression is selectively depleted from MNs. $\mathrm{Hb} 9$ and indicated Hox proteins are expressed normally. 

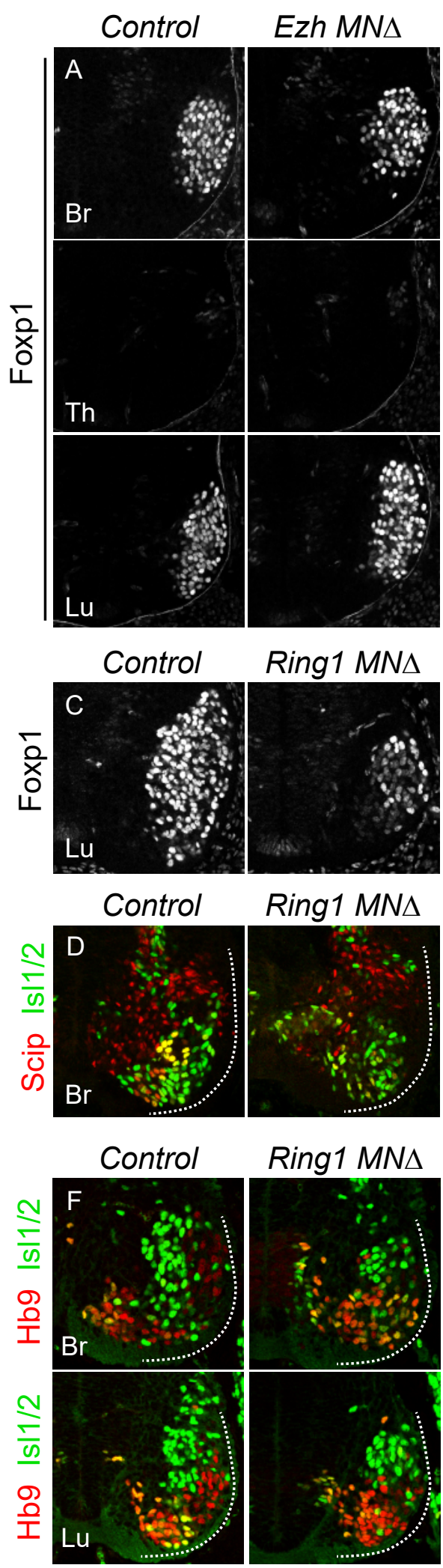
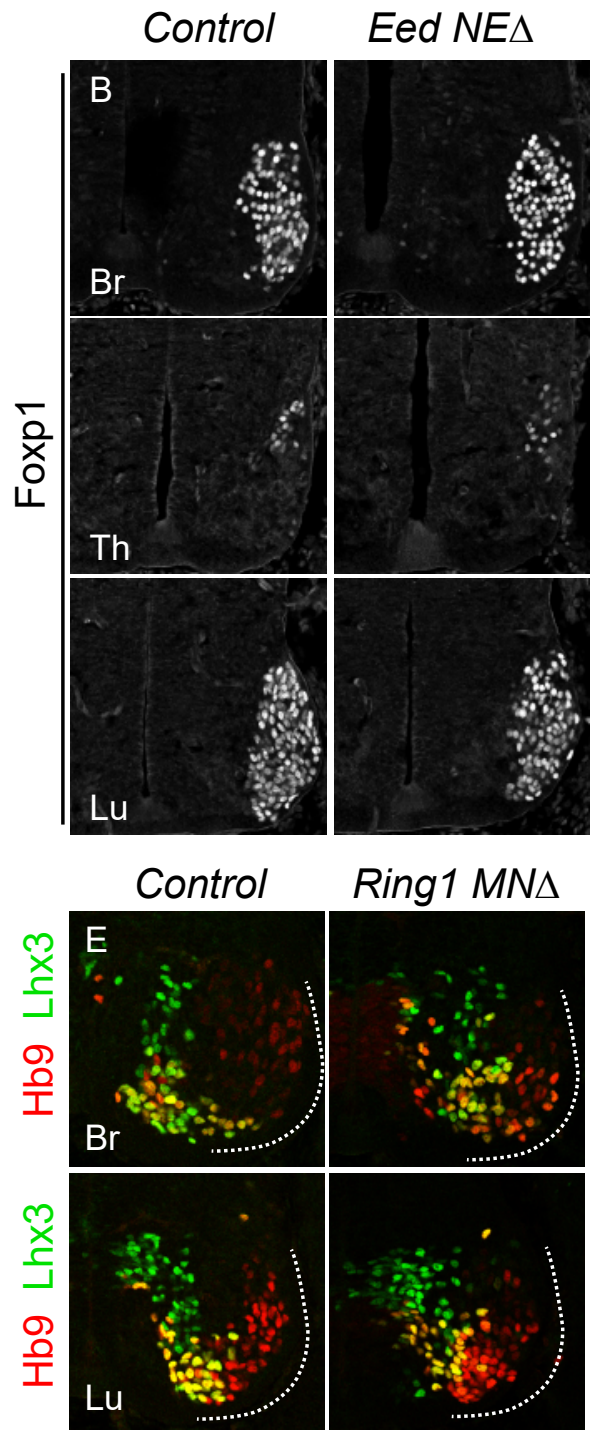

Supplementary Figure 2. Analyses of MN subtypes in PRC mutant mice.

$(\mathrm{A}, \mathrm{B})$ Foxp1 expression is unaffected at brachial, thoracic, and lumbar levels in Ezh ${ }^{M N \Delta}$ and Eed ${ }^{N E \Delta}$ mice. (C) Reduced Foxp1 expression in lumbar segment of Ring $1^{M N \Delta}$ mice. (D) Reduced expression of phrenic motor column (PMC) markers (Scip ${ }^{+}$, Is $11 / 2^{+}$) in rostral brachial segments of Ring $1^{M N \Delta}$ mice. (E) Expression of MMC neuron (Hb9, Lhx3) markers in brachial and lumbar segments of Ring $1^{M N \Delta}$ mice. (F) Expression of HMC markers ( $\mathrm{Hb} 9$, Isl1/2) in brachial and lumbar segments of Ring $1^{M N \Delta}$ mice. 
bioRxiv preprint doi: https://doi.org/10.1101/2021.08.09.455667; this version posted August 11, 2021. The copyright holder for this preprint (which was not certified by peer review) is the author/funder, who has granted bioRxiv a license to display the preprint in perpetuity. It is made available under aCC-BY 4.0 International license.

A

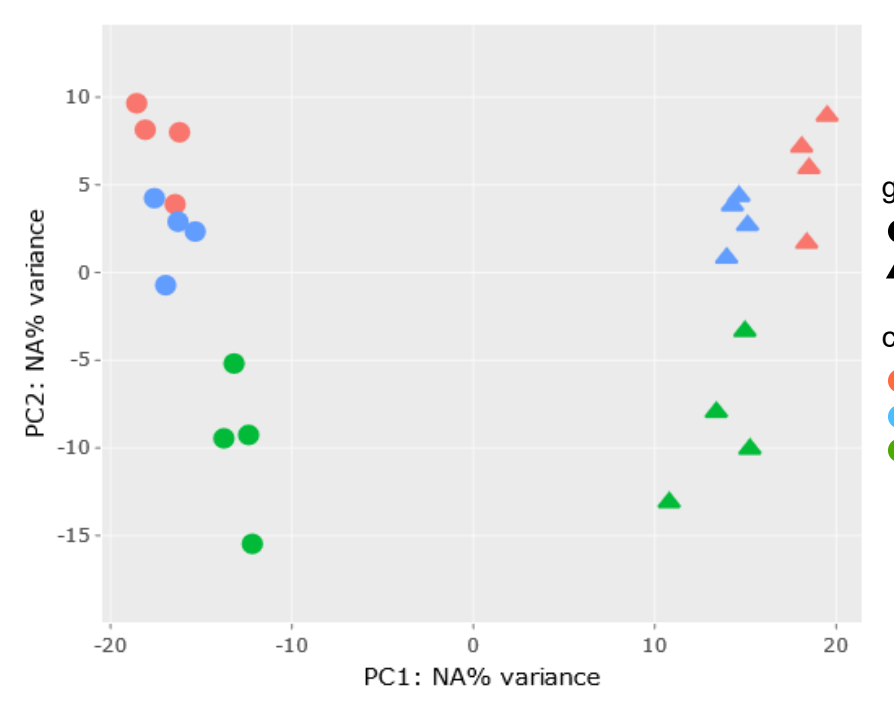

B

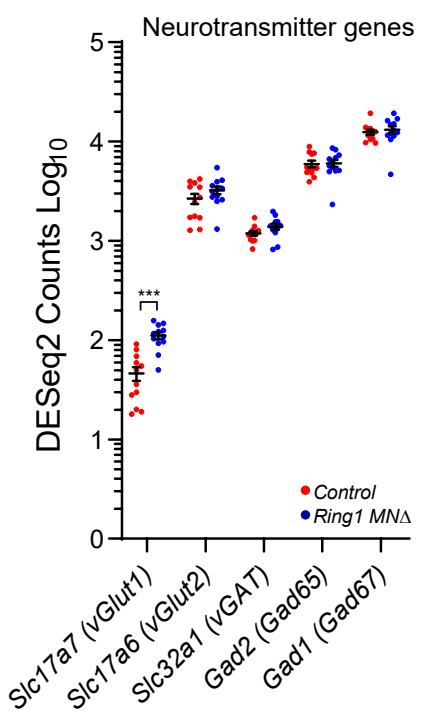

C

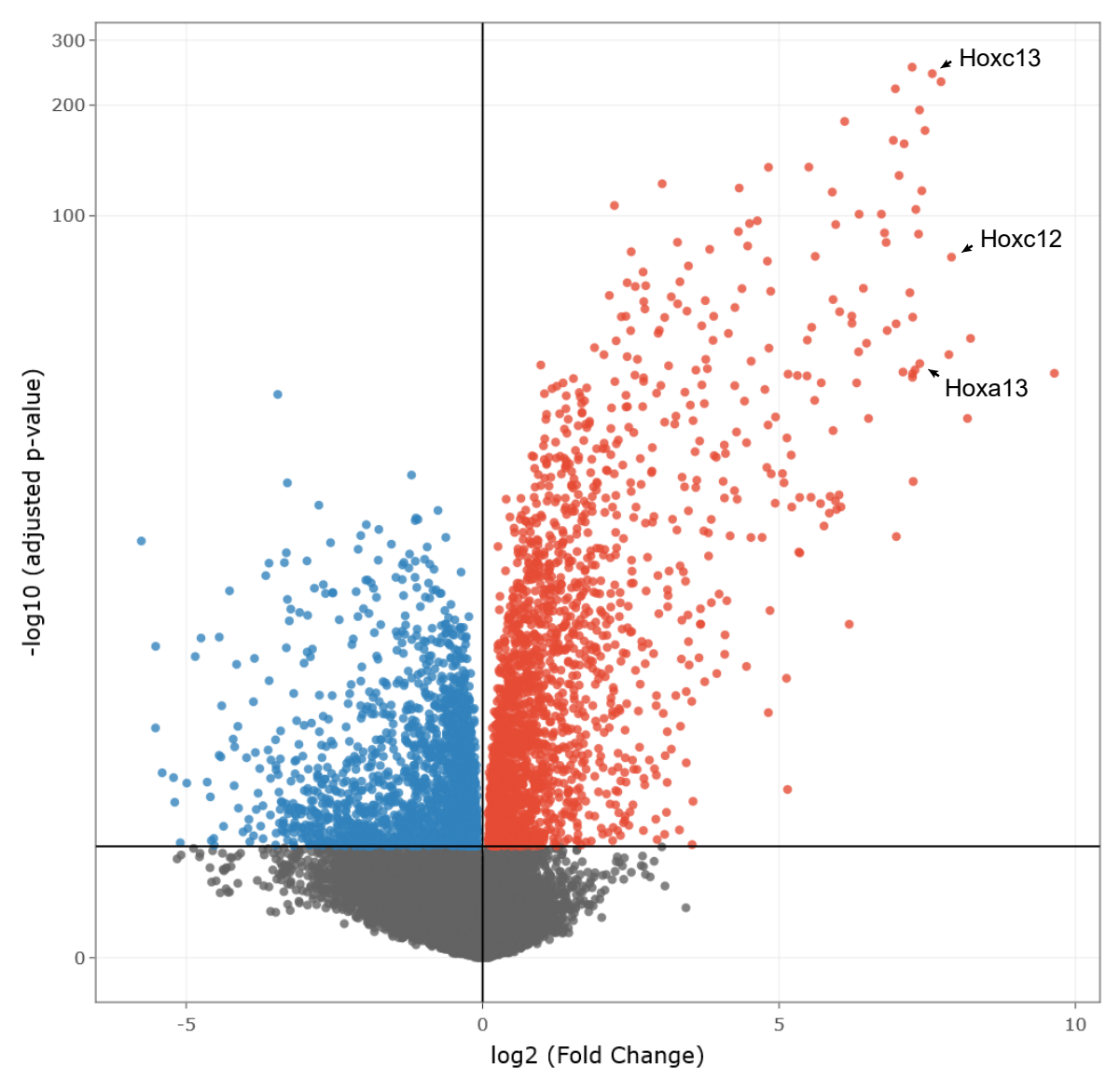

Supplementary Figure 3. RNAseq analyses of Ring1 mutant mice.

(A) PCA plot of RNAseq samples. (B) Plot of neurotransmitter encoding genes in control and Ring $1^{M N \Delta}$ mice. Commonly used gene names are shown in parenthesis. Expression of S/c17a7 is increased in Ring $1^{\mathrm{MN} \Delta}$ mice, although the absolute DESeq2 counts were still relatively low (46.3 +/- 7.2 in controls versus $111.1+/-9$ in Ring $1^{M N \Delta}$ mice, $\left.p=0.000012\right)$. Elevated expression of Gad1 in controls and mutants may be due to presence of spinal interneurons in sorted samples. (C) Volcano plot of upregulated (red) and downregulated (blue) genes. Three caudal Hox genes are indicated. 


\section{upregulated}

\section{Foxg1}

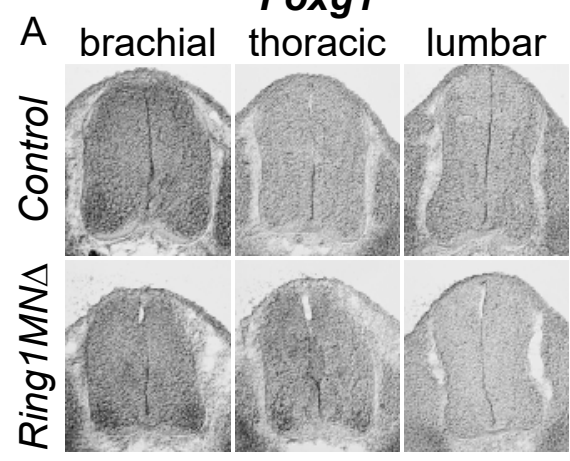

Six6

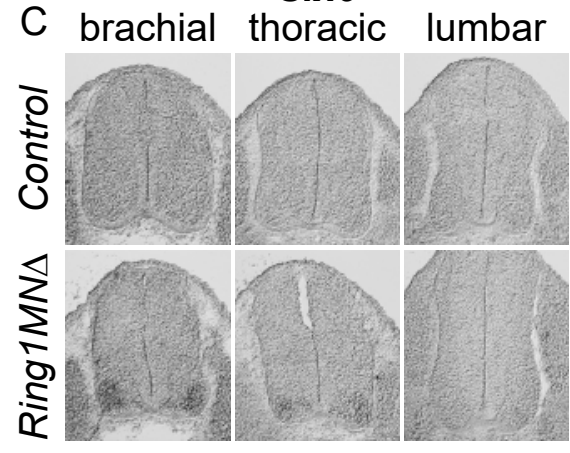

E brachial thoracic lumbar

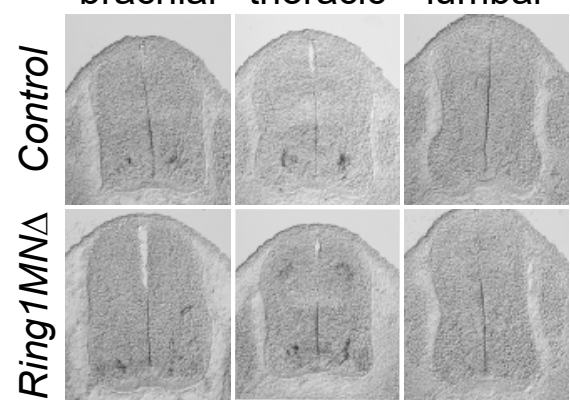

B
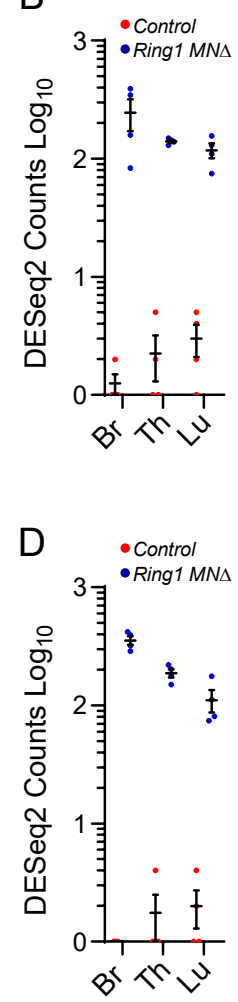

$\mathrm{F}$

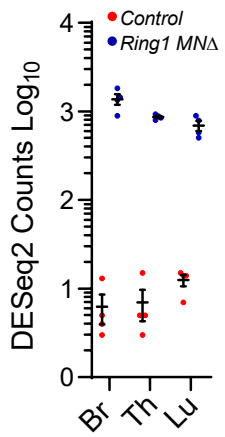

upregulated

Shox2

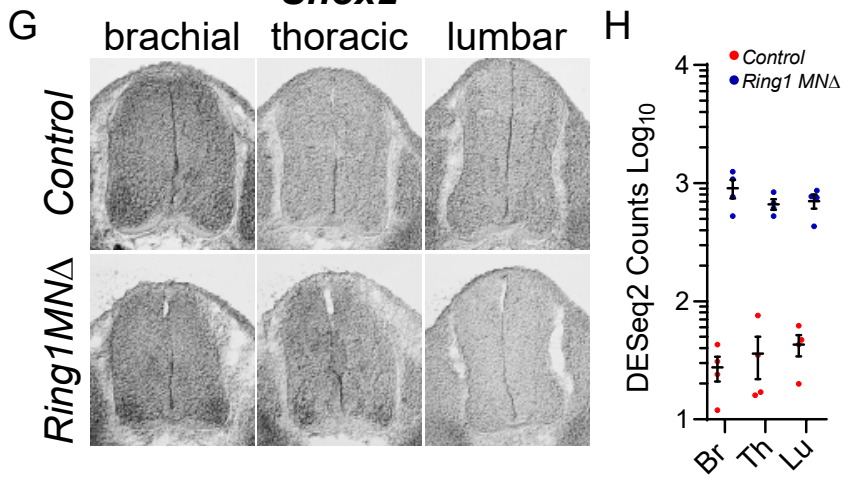

Nkx2.1

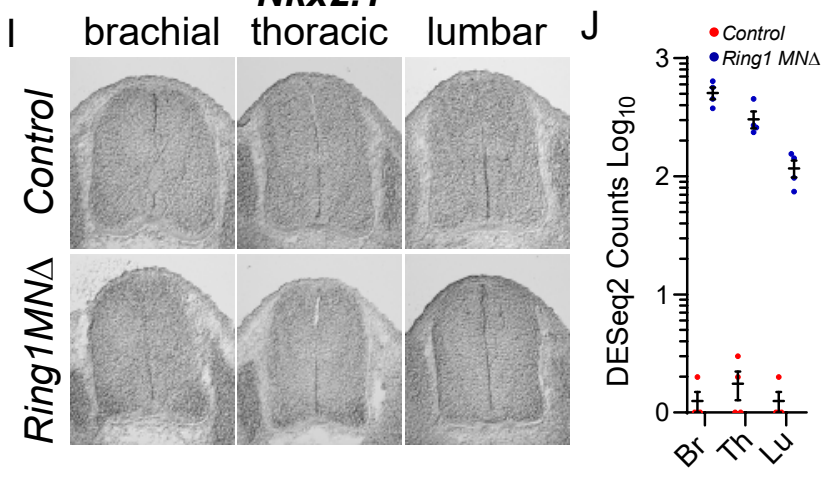

\section{downregulated}

$\mathrm{K}$

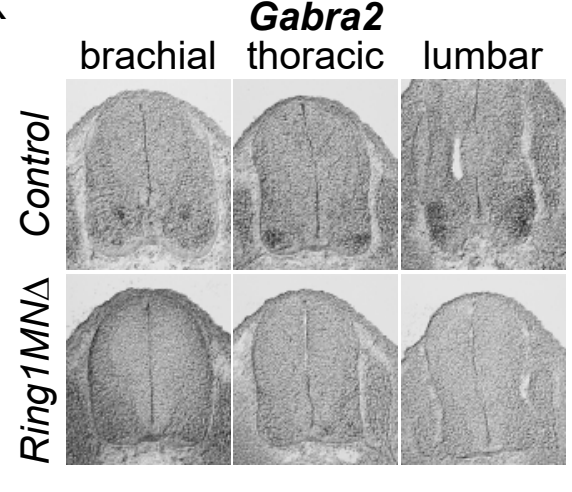

$\mathrm{L}$

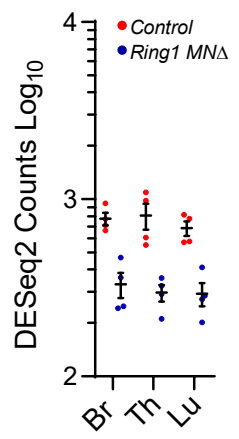

\section{Supplementary Figure 4. Validation of downregulated genes from Ring $1^{M N \Delta}$ RNAseq.}

(A,C,E,G,I) In situ hybridization of selected upregulated genes from the Ring $1^{M N \Delta}$ RNAseq. Images show sections at brachial, thoracic, and lumbar levels from E12.5 control and Ring $1^{\mathrm{MN} \Delta}$ mice. (B,D,F,H,J) Graphs of DESeq2 counts for each upregulated gene in each segments. (K) Analysis of the downregulated gene Gabra2 by in situ hybridization. (L) Graph of DESeq2 counts for Gabra2 in each segment. 


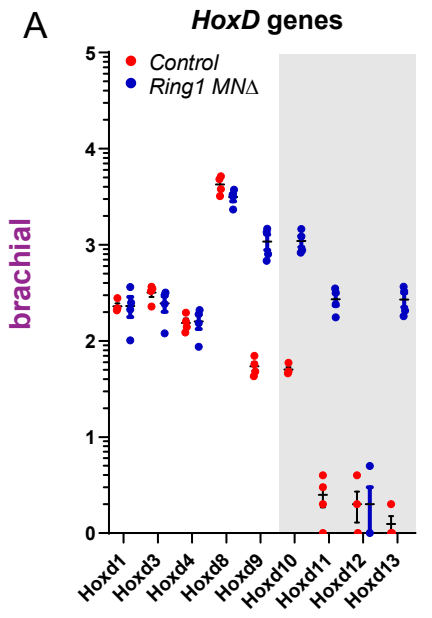

B
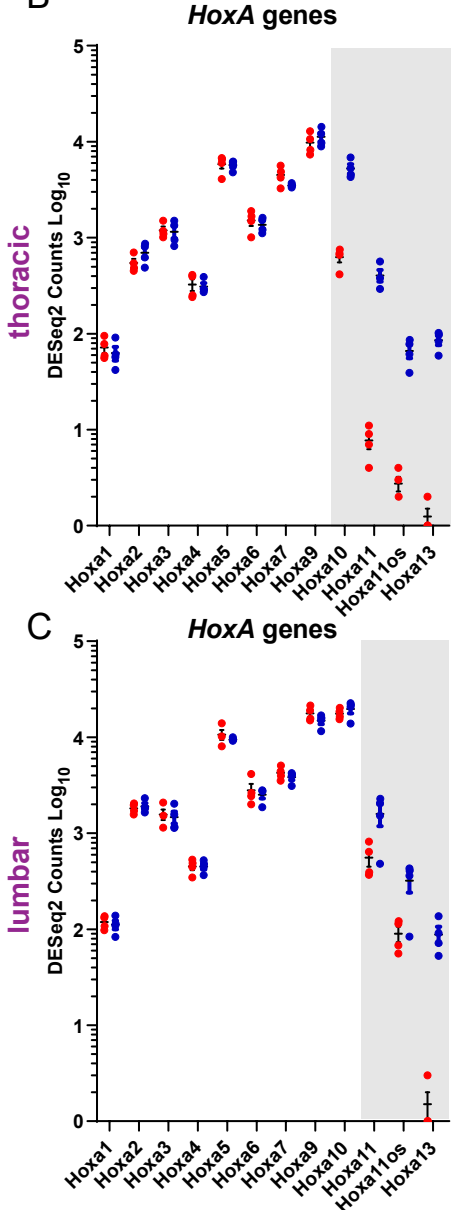
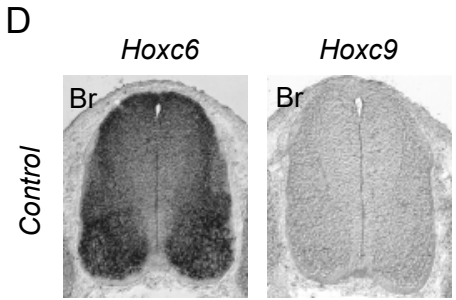

Hoxc9
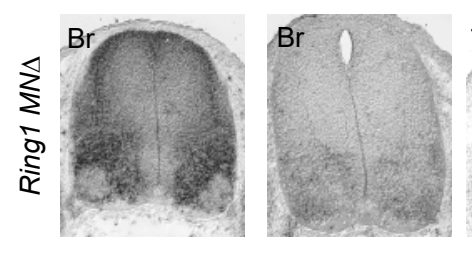
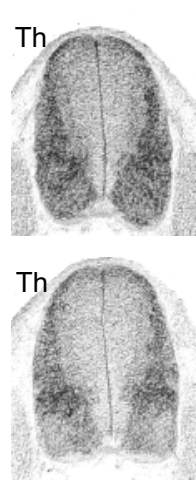

HoxB genes
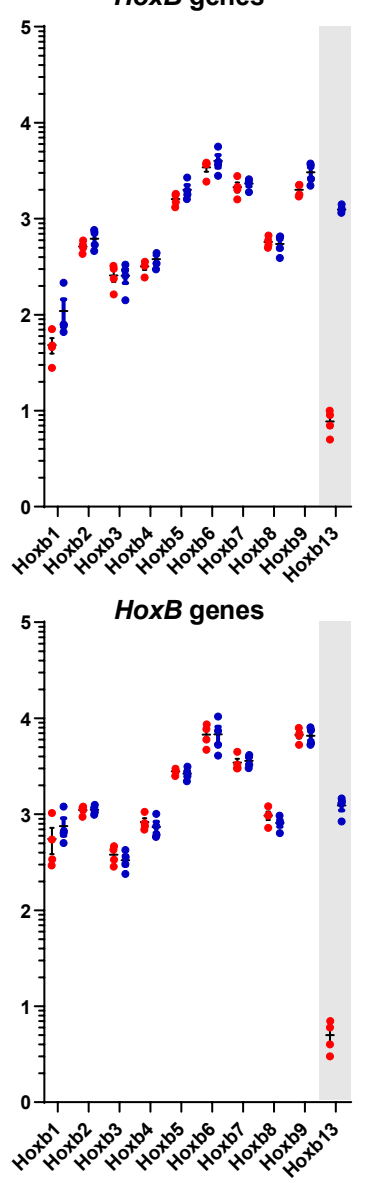

HoxC genes

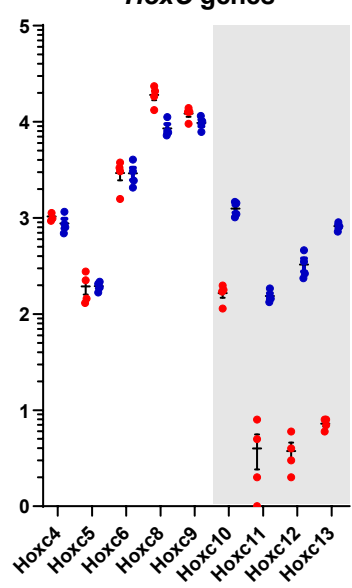

HoxC genes

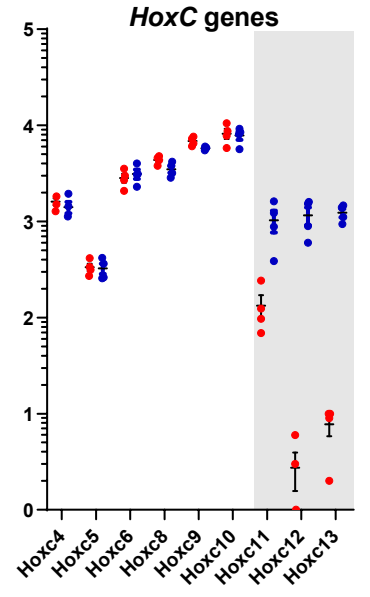

HoxD genes

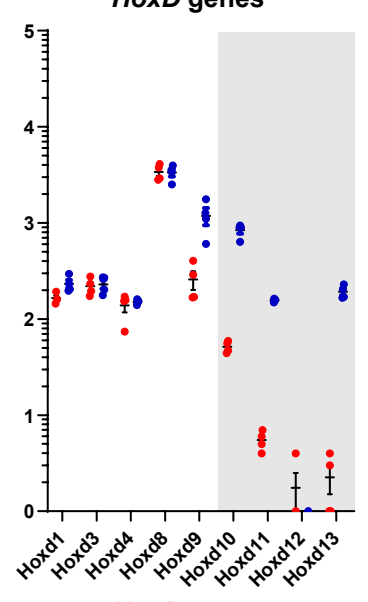

HoxD genes

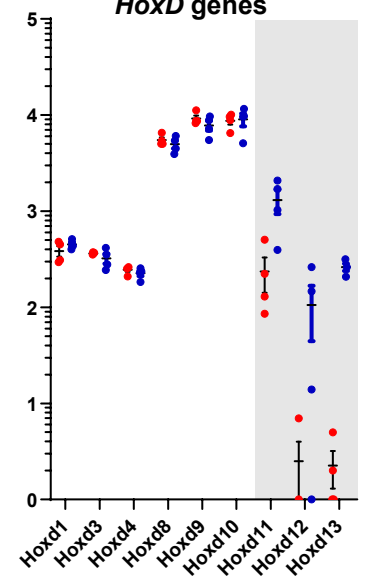

Supplementary Figure 5. Derepression of caudal Hox genes in Ring $1^{M N \Delta}$ mice.

(A-C) DESeq2 counts of $\operatorname{Hox} A, \operatorname{HoxB}, \operatorname{Hox} C$, and $\operatorname{HoxD}$ gene clusters in brachial (A), thoracic (B), and lumbar (C) segments. Gray-shaded regions highlight Hox genes that are derepressed in MNs of Ring ${ }^{1 M N}$ mice. In lumbar segments, expression of Hox10 genes is not reduced in Ring1 mutants, although Hox13 genes are derepressed. (D) In situ hybridization of Hoxc6 and Hoxc9 in Ring $1^{M N \Delta}$ mice at brachial (Br) and thoracic (Th) levels at E12.5. In brachial segments, expression of Hoxc6 is lost from MNs, and Hoxc9 is expressed, similar to the analyses of Hox protein expression. In thoracic segments, Hoxc9 expression is reduced in $\mathrm{MNs}$. 
bioRxiv preprint doi: https://doi.org/10.1101/2021.08.09.455667; this version posted August 11, 2021. The copyright holder for this preprint (which was not certified by peer review) is the author/funder, who has granted bioRxiv a license to display the preprint in perpetuity. It is made available under aCC-BY 4.0 International license.

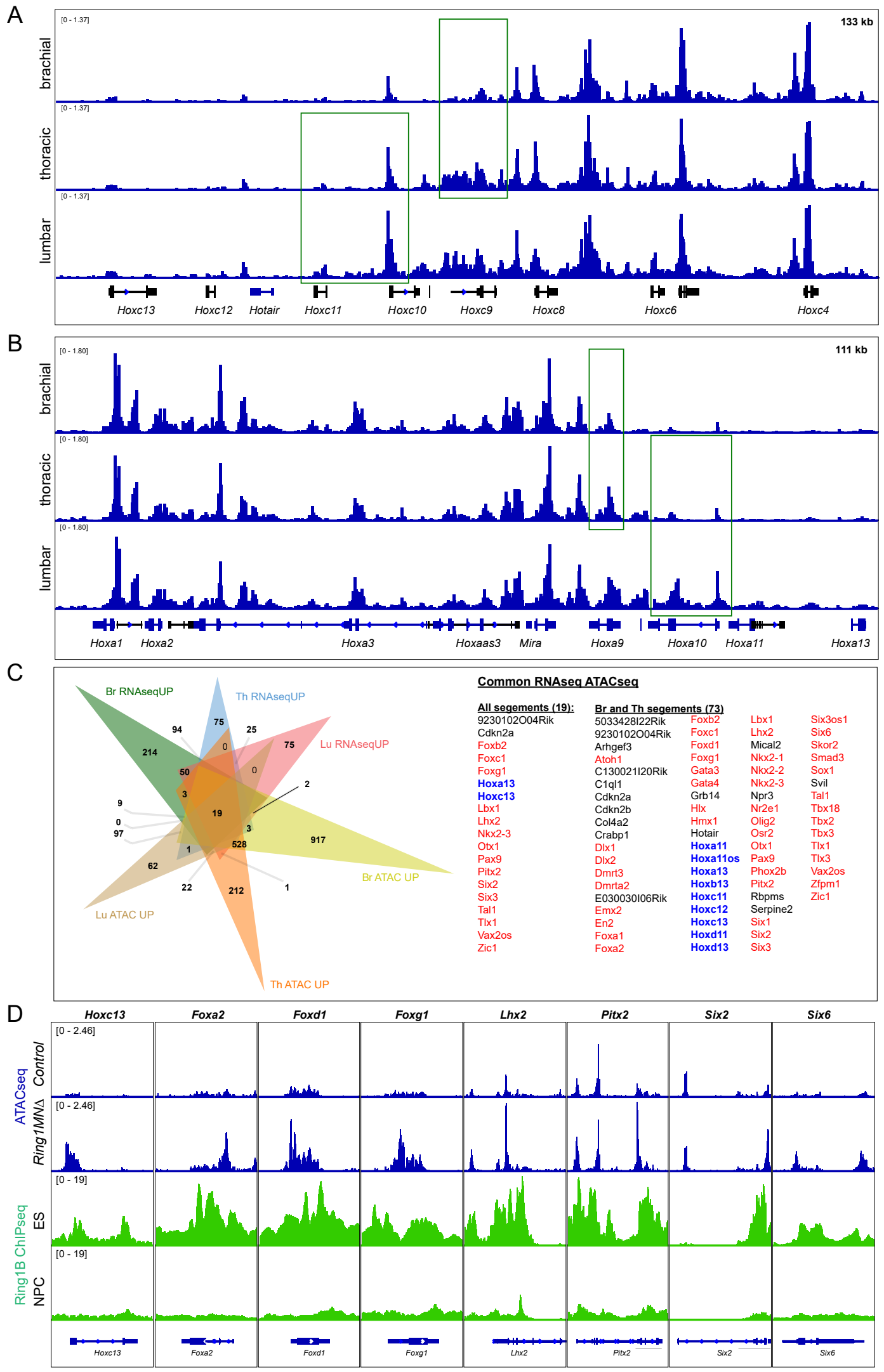

Supplementary Figure 6. Integrative analysis of RNA and ATACseq results

$(\mathrm{A}, \mathrm{B})$ IGV browser view of ATACseq tracks of the HoxC cluster (A) and HoxA cluster (B) in control mice. The peaks highlighted with green box indicate regions that gain accessibility in more caudal segments. (C) Venn diagram of upregulated genes (RNAseqUP) and genes that gain chromatin accessibility (ATACseqUP) in all segments. Genes that are upregulated and gained accessibility for all segments (19 genes) or $\mathrm{Br}$ and $\mathrm{Th}$ segments (73 genes) are listed on the right. Hox genes are highlighted in blue, other transcription factors in red. (D) IGV browser view comparing ATACseq tracks from brachial segments (control and Ring $1^{M N \Delta}$ mice) with Ring1B ChIPseq tracks from ES and neural progenitor cells (NPC). Regions that gain accessibility in Ring1 mutants correspond to regions bound by Ring1B in ES cells. 

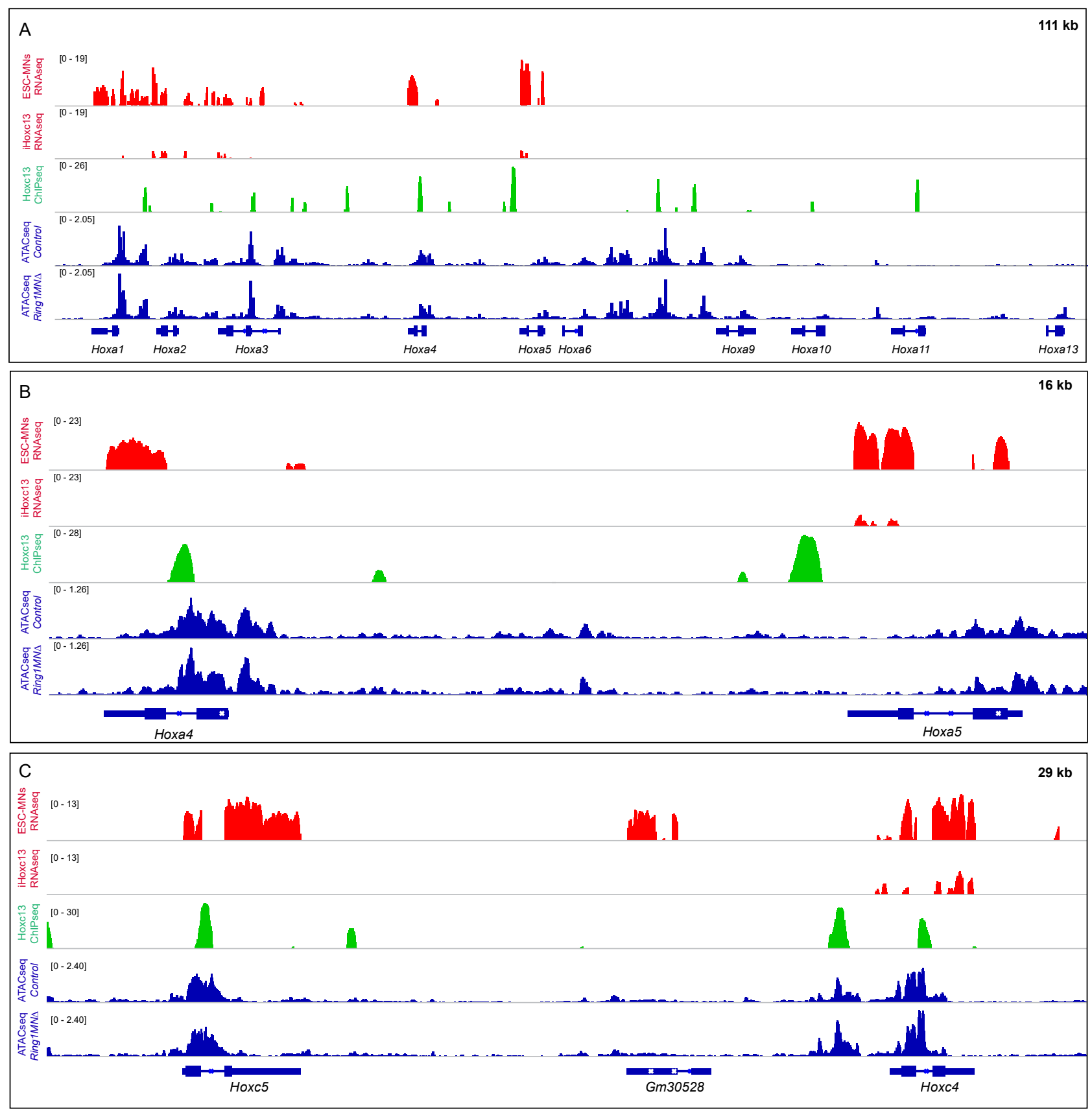

Supplementary Figure 7. Comparison of Hoxc13 binding and accessibility in control and Ring $1^{M N \Delta}$ MNs

(A) Effects of Hoxc13 expression in ESC-MNs at the HoxA locus. Top panels show IGV browser views (log scale) of RNAseq (red) and ChIPseq tracks (green). Induced Hoxc13 represses expression of Hoxa1-Hoxa5 genes and binds near multiple HoxA genes. Bottom panels show ATACseq in brachial control and Ring1 mutant MNs at the HoxA cluster (blue). Bottom panels show ATACseq in brachial control and Ring1 mutant MNs at the HoxA cluster. (B,C) Magnified views of Hoxc13 binding, RNA expression, and ATACseq results at Hox4-Hox5 genes in the HoxA and HoxC clusters. 